\title{
A Network Perspective on Inter-Organizational Transfer of R\&D Capabilities: A Study of International Joint Ventures in Chinese Automobile Industry
}

By: Zheng Zhao, Jaideep Anand and Will Mitchell

Working Paper Number 362

February 2001 


\title{
A network perspective on inter-organizational transfer
}

\author{
of $R \& D$ capabilities: A study of international joint \\ ventures in Chinese automobile industry
}

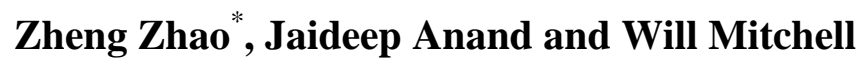 \\ University of Michigan Business School, Ann Arbor, MI, 48109-1234, USA
}

\begin{abstract}
Multinational enterprises' transfer of R\&D capabilities to their international joint ventures in the less developed countries has been an emerging phenomenon. The purpose of this study is to understand the transfer of $R \& D$ capabilities between organizations embedded in drastically different organizational contexts using a network perspective. We identified different networks involved in the R\&D capability transfer process from the perspectives of source organization, recipient organization and the interface between them, and analyzed the impact of different attributes of these networks on the effectiveness of R\&D capability transfer, based on the notion that R\&D capabilities are largely collective knowledge.
\end{abstract}

Key Words: R\&D capabilities, networks, international knowledge transfer, joint ventures, collective knowledge.

\footnotetext{
* Corresponding author. Tel.: 810.714.2923 e-mail: janezhao@umich.edu
} 


\section{Introduction}

Firms' capabilities to recombine their resources to create new innovations have been deemed critical in determining survival and success (Nelson and Winter 1982; Prahalad and Hamel 1990; Schumpeter 1934; Selznick 1957). R\&D capabilities are the capabilities of a firm that enable effective knowledge recombination and integration among different sources of innovation to create new products and processes. Unlike transferring product/process technologies or manufacturing technologies, transferring R\&D capability is not just about transmitting codified or equipmentembedded knowledge and individual skills, but more about transferring and cultivating tacit and organizationally embedded routines of how to integrate knowledge and skills to generate value.

The theoretical tools used in the knowledge transfer literatures traditionally come from two camps. The first camp is led by transaction costs economics (TCE) (Hennart 1988; Teece 1986; Williamson 1981) and 'the internalization school' (Dunning 1988; Hymer 1960), which attends more on the basic behavioral assumption of opportunism, and deals with the motivation, incentive mechanism, and safeguard mechanisms involved in the knowledge transfer. The second camp of theoretical tools is the resource/knowledge-based view and evolutionary theories (Argote and Ingram 2000; Cohen and Levinthal 1990; Fiol and Lyles 1985; Grant and Baden-Fuller 1995; Kogut and Zander 1992; Kogut and Zander 1993; Levitt and March 1988; Nelson and Winter 1982; Spender 1996). This camp cares less about opportunism assumption than human and organizational cognitive abilities. The main concern of this camp is to understand the knowledge generation and coordination that occurs within and across organizations.

Recently, a third camp of theory - network theory (Ahuja 1996; Burt 1992; Granovetter 1985; Gulati 1998; Powell, Koput and Smith-Doerr 1996; Uzzi 1997) has started to evolve and join force with the two traditional camps to explore the nature and dynamics of the knowledge creation, 
coordination and transfer among network members. With the tools of the network theory, we can understand better the storage and movement of knowledge among multiple agents in a empirical setting, rather than looking at knowledge transfer as an isolated interaction between two individual agents.

The key contribution of this paper lies in its extension of the prior studies of knowledge transfer through adopting both the network and knowledge-based lenses to understand the effects of source organization's teaching capability, recipient organization's learning capability and the interface structure between them on the success of capability transfer. Two key network factors are studied: network experience/knowledge stock and network structure. Three sets of propositions are developed in this paper. The first set predicts the effect of source organization's business network's knowledge stock on the effectiveness of R\&D capability transfer. The second set looks at the effect of recipient organization's business network's knowledge stock on the effectiveness of the R\&D capability transfer. The third set predicts the effects of different properties of the network connecting the source and recipient, which is called "bridge network" in this paper, on the effectiveness of the transfer of R\&D capabilities.

Although the teaching intent of the source organization and the learning intent of the recipient organization are important factors for the extent of capability transfer, we do not explore them explicitly and leave them as control variables in this paper, in order to conduct a focused study on the coordination aspects of knowledge transfer mechanisms.

The importance of R\&D capability is not only realized by firms in the industrialized countries but also acknowledged by those in the less developed countries (LDCs) (Baranson 1977). The governments of many LDCs have issued policies to solicit not only the greater local production content but also greater local knowledge content of the multinational enterprises (MNEs) production in their countries. In recent years, under increased pressure from the local governments 
and the more globalized and intensified competition in their host countries' markets, MNEs start to transfer some R\&D capabilities to their business partners in the LDCs.

The activities of transferring R\&D capabilities in Chinese auto industry is selected as the empirical setting for this study because (1) there is growing evidence of MNE's transferring R\&D capability to their joint ventures in this industry, and (2) it provides a natural setting to examine the interaction between previously isolated networks. There are significant technological, cultural and managerial barriers between the source organization and the recipient organization, which provides an opportunity to study how firms apply their network knowledge stock and design their interpartner network structure to overcome the transfer difficulties and achieve effective capability transfer.

The findings from the initial field work support the validity of the propositions of this paper in the following areas: First, the network stock of alliance, country and firm experiences can enhance both partners' alliance capability (Anand and Khanna 2000), source organization's teaching capability and the recipient organization's learning capability. Second, the intensity and scope of the network structure built at the interface between the source and the recipient organizations have significant impact on the effectiveness of R\&D capability transfer.

This paper will proceed in the following order (1) a theoretical review of key concepts knowledge, capability, and R\&D capability in particular (2) some theoretically derived propositions and hypothesis of mechanisms that enable the effective transfer of R\&D capabilities from both the resource-based and network perspectives (3) research methods, variables and data and (4) some initial empirical evidences of the propositions collected from field observations and interviews related of MNEs' transferring of R\&D capabilities in the Chinese auto industry. 


\section{Organizational knowledge and $R \& D$ capabilities}

In order to discuss the requirements and mechanisms for transferring organizational capabilities, we must first clearly understand the meaning and characteristic dimensions of organizational capabilities. This can be achieved by looking at the conceptual relationships between organizational capabilities, organizational knowledge, and organizational routines.

First let us consider the relationship between organizational knowledge and organizational capabilities. Many theorists have agreed on a taxonomy scheme of knowledge based on two general dimensions: (1) embeddedness and (2) tacitness (Kogut and Zander 1992; Nonaka and Takeuchi 1995; Spender 1996). Based on these two dimensions, a two-by-two array of knowledge taxonomy is given by Spender (1996). Conscious knowledge refers to the explicit individual knowledge, such as codified personal skills. Automatic knowledge is the tacit individual knowledge, such as intuition and tacit experiences. Objectified knowledge refers to the explicit embedded knowledge, such as codified organizing principles and procedures involving multiple agents or functional groups. Collective knowledge is the tacit embedded knowledge, such as uncodified routines, shared code or coding scheme, and organizational culture. This tacit and embedded knowledge involves the group or organization's collective memory or collective interpretive scheme (Fiol and Lyles 1985; Levitt and March 1988), organizing principles of social relations (Kogut and Zander 1992; Nelson and Winter 1982), architectural knowledge and competences (Henderson and Clark 1990; Henderson and Cockburn 1994) and routines of interactions among member, tool and tasks (Argote and Ingram 2000).

Among these four types of knowledge, collective knowledge is considered as "the most secure and strategically significant kind of organizational knowledge" and the source for competitive advantage or long streams of high value-added "Penrose rent" (Spender 1996), the key 
asset of the firm that can resolve the paradox between desired transfer and unwanted imitation (Kogut and Zander 1992; Argote, 2000), and therefore, the key component of organizational capabilities or core competencies (Kogut and Zander 1992: 384; Prahalad and Hamel 1990). Therefore, organizational capabilities imply largely the organizational collective knowledge. In a product development cycle, different capabilities with different levels of tacitness and embeddedness, such as R\&D capabilities, manufacturing capabilities, and marketing capabilities are needed at various stages.

To understand the content of organizational capabilities, one also needs to address the relationship between organizational routines and capabilities. Nelson and Winter (1982) describe organizational routine as "organizational skill" or "what [the firm] knows", or the system of coordinating relations among the people and tasks - the relations that combine the knowledge carried by individuals and various tasks into a productive performance. We can consider routines as small-scaled organizational collective knowledge, whereas organizational capabilities as the combination of routines of various levels and functions 1 .

R\&D capabilities can be defined as the capabilities of a company as a whole to create new knowledge, disseminate it throughout the organization, and embody it in products, services, and systems. Compared to manufacturing capabilities, R\&D capabilities have more collective knowledge content (Nonaka and Takeuchi, 1994). This is because (1) R\&D activities are performed when knowledge recombination is less finalized and not yet fully embedded into products, organizational structures, procedures and documents, or high in unprovenness and

\footnotetext{
${ }^{1}$ Some theorists include physical assets, explicit and individual knowledge in the organizational capabilities (Capron and Mitchell 1999 working paper). It is true that firms' collective knowledge cannot exist without the physical knowledge carriers and individual knowledge. However, for simplicity, we would like to focus only on the collective knowledge in the conceptualization of organizational capabilities.
} 
uncertainty (Pavitt 1990; Szulanski 1996). Therefore the coordination among different knowledge carriers is more tacit and requires greater experience and on-the-spot discretion. (2) R\&D activities require systemic collaboration among more functional departments (Pavitt 1990). (3) R\&D activities span across multiple stages in the product development cycle.

Furthermore, R\&D capabilities vary in the level of tacitness and embeddedness depending on (1) the level of complexity and maturity of the knowledge set embedded in the products or processes, which are the outcome of the R\&D activities, and (2) the stage of R\&D activities (Buckley and Casson 1976). The more complex the product or process and the earlier the R\&D stages, the more extensive the division of labor in R\&D activities, and the more coordination among different knowledge holders and the more difficult the recombination of their knowledge. For example, the R\&D activities carried out by the GM tech center in the U.S. involves higher earlystage components and requires large asset investment and managerial coordination, comparing to its R\&D branches in other countries, which mostly perform the end stage of R\&D activities, and therefore much smaller in size and low in coordination capacity.

In summary, organizational capabilities are the kind of organizational knowledge that is tacit and embedded among functional units and group of knowing entities. Organizational capabilities reside in the organizing principles governing interactions of various knowledge carriers, and involve norms, beliefs, routines, codes and coding schemes among organizational members. The two key dimensions of capabilities are tacitness and embeddedness. R\&D capabilities are the most tacit and embedded among various capabilities of the firm. 


\section{Transfer of $R \& D$ capabilities}

Although there exists a large body of literature on domestic or international technology transfer, few studies have been done to focus into the issue of capability transfer, which is subset of the notion of knowledge transfer, since capability, based on the operational definition in this paper, can be boiled down to one type of the knowledge - collective knowledge. With the understanding of the content and attributes of the collective knowledge involved in manufacturing firms' R\&D activities, we can translate the issue of capability transfer into the transfer of collective knowledge.

When a capability or collective knowledge has greater degree of tacitness and

embeddedness, there are two consequences: the positive consequence is that this capability is more valuable in securing competitive advantage because it is less imitable than explicit knowledge (Amit and Schoemaker 1993; Dierickx and Cool 1989; Penrose 1959), whereas the negative one is that this capability is more difficult to be transferred to other operations of the firm than individual or explicit knowledge.

MNEs’ R\&D activities in the LDCs are mostly performed at the end stage of the R\&D cycle, with the tasks such as debugging and adaptation of the general design to the local environment (Buckley and Casson 1976). In this paper, we will focus on MNEs' transfer of latestage $R \& D$ capabilities to their partners in the Chinese auto industry.

\subsection{Dynamic process of $R \& D$ capability transfer}

The mechanisms for knowledge transfer can be categorized in two general types (1) discrete movement of knowledge from one site to the other and (2) modification of the recipient's knowledge stock through continuous interactions between the recipient and the source (Argote and 
Ingram 2000) ${ }^{2}$. To discretely move capabilities with high collective knowledge content requires the movement of entire knowledge group, which involves physically moving majority (if not all) human member, equipments/tools, functional jobs abroad to the recipient site. In business practices, this type of capability transfer happens when the recipient organization acquire or merge with the source organization. In the context of international technology transfer through international joint ventures (IJVs), this mechanism is rarely used. Capability transfer through alliances usually adopts the second mechanism, which is to modify the recipient organization's existing routines through inter-partner teaching and learning.

In the process of transferring $\mathrm{R} \& \mathrm{D}$ capabilities through modifying the knowledge stock of the recipient, two levels of knowledge actions are happening. Level I knowledge transfer only involves individual and objectified knowledge, such as equipment-embodied knowledge (e.g., analytical and design equipments), document-embodied (e.g., blueprints, patents and testing procedures) and transferring human-embodied skills (e.g., design skills, analytical skills and testing skills) ${ }^{3}$. At this level, the recipient's existing routines are not seriously challenged and changed (Argyris and Schon 1978; Fiol and Lyles 1985; Nonaka and Takeuchi 1995).

Level II knowledge transfer, on the other hand, refers to the transfer of collective knowledge components. In the process of Level II knowledge transfer, the recipient's existing routines will be

\footnotetext{
${ }^{2}$ In a similar categorical scheme, Baum and Ingram (1998) proposed three routine transfer mechanisms (1) directly hiring routine-carriing employees from other organizations (2) learning through personal contact and formal relationships, and (3) mimetic learning or vicarious learning through methods such as benchmarking and reverse engineering. The last two were suggested by Miner and Haunschild (1995).

${ }^{3}$ Many learning (or knowledge-based) theorists (Miner and Haunschild 1995, Huber 1991, Levitt and March 1988) have argued that knowledge can be copied or imitated without direct contact, through vicarious learning or mimicking.
} 
challenged, modified or even eliminated, and newer routines will be developed to effectively coordinate and recombine the acquired Level I knowledge and generate new knowledge (Argyris and Schon 1978; Fiol and Lyles 1985; Nonaka and Takeuchi 1995).

Level II transfer, due to its involvement with more tacit and organizational-embedded knowledge, is much harder and more time-consuming to be implemented (Dierickx and Cool 1989; Teece 1986).

The focus of the following discussion is the Level II R\&D capability transfer through the mechanisms of continuous interaction between the source and the recipient organizations. Also, some limit should be put into the discussion. Although R\&D capabilities are considered fungible (Anand 2000), not all R\&D capabilities or routines can be or need to be transferred. Examples are organizational norms and values that are specific to the context of the source firm and the manager's intrinsic character-specific managing styles.

\subsection{Requirements for effective transfer of capabilities}

Based on the understanding of the content and attributes of capabilities and the characteristics of the source and recipient organizations, we can systematically identify the requirements for effective transfer of capabilities, which will further explain the effectiveness of transfer mechanisms used in the field.

\section{Requirements based on the tacitness of capabilities}

To transfer tacit knowledge, three requirements must be implemented into the transfer process. First, intimate personal contact between the transferor and the transferee must be

Level I routine transfer corresponds to this type of activities, which tend to be superficial and reliant on codified and observable forms or knowledge carriers, and cannot deliver the collective knowledge and belief systems. 
guaranteed. Transferring tacit knowledge can be done through direct interaction, first-hand observation, exposure to the source entity's working environment and socialization process (Nonaka and Takeuchi 1995; Polanyi 1962). Second, learning of tacit knowledge should be carried out by doing. Nelson and Winter pointed out that organizations must "remember by doing" in order to acquire the tacit aspect of knowledge (1982: 99). Levitt and March (1988) echoed this point by saying capability formulation is a process of collective memory accumulation through practices of tasks. Lastly, long-term commitment of collaboration by both sides of the transfer must be secured in order to transfer tacit knowledge, since the cumulative nature of the transfer of tacit knowledge engenders time compression diseconomy (Dierickx and Cool 1989), and thus calls for long-term and stable relationships between the source and recipient organizations (Nelson and Winter 1982; Teece 1986).

\section{Requirements based on the embeddedness of capabilities}

Embedded knowledge or a certain routine dwells in the interrelationships among a group of people. Therefore, the indivisible knowing entity of the embedded knowledge is not individual people but a group of people, which we call the "knowledge group". Transfer of embedded knowledge therefore, is a process of adopting the embedded knowledge carried by the knowledge

group of the source side, which we call the "source group", to the knowledge group of the recipient side, which we call the "learning group". In other words, embedded knowledge cannot be transferred in an individual-to-individual manner. Its effective transfer must be carried out by the effort and interaction between the source group and the learning groups. This implies two requirements for knowledge transfer: First, teaching should be done by the source group, in which the capability or routine in question is embedded. Second, learning should be carried out by the learning group, to which the capability or routine in question will be transferred. Teece (1986:29) 
has suggested the notion of group-to-group knowledge transfer by saying: “... it will often not suffice just to transfer individuals. While a single individual may sometimes hold the key to much organizational knowledge, group support is often needed, since organizational routines may need to be transferred." Hedberg also states: “Although organizational learning occurs through individuals, it would be a mistake to conclude that organizational learning is nothing but the cumulative result of their members' learning. Organizations do not have brains, but they have cognitive systems and memories. As individuals develop their personalities, personal habits, and beliefs over time, organizations develop worldviews and ideologies. Members come and go, and leadership changes, but organizations' memories preserve certain behaviors, mental maps, norms and values over time (Fiol and Lyles 1985)

\section{Requirements based on attributes of the source and the recipient organizations}

Transfer of capabilities to LDCs has different implications from that to developed countries in the following aspects: First, larger technological and managerial gaps exist between the source and the recipients organizations. Second, host country environment are usually more complex and dynamic (Luo and Peng 1999). Lastly, the cultural distance between the source and the recipient organizations are usually greater.

Therefore, two additional requirements are needed for the DC-to-LDC capability transfer: First, the cultural, managerial distance between the source and the recipient must be reduced. To achieve this, previous host country experience and multinational experience of the source organization and the IJV experience of the recipient organization can be of great help (Dunning 1988; Johanson and Vahlne 1977; Kogut and Singh 1988; Luo and Peng 1999).

Second, the recipient's preexisting routines must be 'unlearned'. This is because the large technological and managerial gap between the source and the recipient organization entails 
obsolescence of the recipient organization's preexisting routines. Therefore, capability transfer implies drastic modification not incremental change of these obsolete routines. Due to the path dependency nature of the existing routines, drastic modification of recipient organization's existing routines is much difficult to carry out than transferring routines to a "clean slate" organization with no previous routines [Baum, 1988; Leonard-Barton, 1992; Argote, 2000], because the former requires one more task in the transfer process: unlearning the previous routines.

\section{Network theory and its implication in capability transfer}

Granovetter (1985) has argued that virtually all economic behaviors in modern life is embedded in networks of social relations that condition economic process. Network ties entail mutual influence between an organization and its network contacts in terms of information, power, resource, and trust, and thus provides different types of benefits such as: trusting relationships, finegrained, timely and continuous information sharing and joint problem-solving arrangement (Ahuja

1996; Burt 1992; Granovetter 1985; Gulati 1998; Powell, Koput and Smith-Doerr 1996; Uzzi 1997). Network has two general implications on the capability transfer process: First, Intra-firm network provides a greater knowledge stock through initial endowment and continuous supply of experiences and knowing entities (i.e. personnel) to its member organizations. Network ties, especially intra-firm ties, enable fine-grained and timely knowledge flows and therefore expand the knowledge stock of each member of the network (Grant and Baden-Fuller 1995; Gupta and Govindarajan 2000). Previous studies in organizational learning in IJVs focus mostly on the individual organizational experience without taking the knowledge-pooling effect of the MNE's subsidiary network into consideration (Luo and Peng 1999). This study aims to include the 
knowledge stocks of both source and recipient's business network to account for their teaching and learning abilities.

Second, alliance inter-partner networks constructs an enduring, intimate and timely knowledge infrastructure allowing tacit and embedded knowledge contents of the capability to be transferred effectively. Most previous studies in international technology transfer dealt with the transfer interface as a discrete and organization-to-organization conduit. This study, however, using network perspective, takes the transfer interface as a network of conduits to reflect the continuous and group-to-group nature of capability transfer.

To sum up, the network-related measures such as network knowledge stock and network knowledge infrastructure can shed new light in understanding the source organization's teaching capability, the recipient organization's learning capability and the enduring, intimate and group-togroup nature of transfer process required for transferring capabilities.

In the following sections, we will discuss three networks involved in each case of transfer of R\&D capabilities - the source organization's business network, the recipient firms business network and the bridge network connecting the source and the recipient organizations. We will also look at the effect of each of these networks on the effectiveness of R\&D capability transfer. Figure 1 shows all agents involved in the R\&D capability transfer activities studied in this paper and knowledge flow among these agents. The ties belong to each of the three networks are also shown in the figure.

$* * * * * * * * * * * * * *$ Figure 1 about here $* * * * * * * * * * * * * * *$

\subsection{Source organization's business network}


Taking on a network perspective, the source organization, which is the MNE partner of the IJV in the empirical context of this study, can be seen as a member of the source organization's business network (hereafter referred to as "source network"), which is defined as the MNE subsidiary network of the source organization. The source organization itself can be either the MNE's parent firm (including core R\&D unit), or a subsidiary unit ${ }^{1}$ (including $R \& D$ branches).

\section{Source network's local knowledge stock}

Previous evidences have shown that tacit and procedural knowledge in areas such as product and process design, distribution and marketing are circulated among members of MNEs' subsidiary network (Gupta and Govindarajan 2000). MNE subsidiaries also share alliance management knowledge through the usage of formal knowledge codifying and sharing routines, central administrative entity to coordinate subsidiaries, and corporate database and newsletters on alliance activities (Anand and Khanna 2000). Evidences from my field observation shown that MNE networks also circulate among their members the country-specific and partner-specific knowledge, and best practices in transferring technologies and building relational capitals with a particular partner in a particular country. Therefore, with the sufficient inter-subsidiary knowledge sharing mechanisms, the source network's knowledge stock regarding alliance capabilities and local knowledge of the host country and the partner firm can be seen as 'public goods' for all members of the source network, and thereby enhances the source organization's teaching capability through reducing the managerial and cultural distance between the source and recipient organizations. In other words, the source unit's teaching capability is embedded in the knowledge stock of the entire source network.

\footnotetext{
${ }^{4}$ Subsidiary unit conventionally is defined as business unit with equal or more than half of the equity share by the core
} 
By defining the source network's local knowledge stock as total country-specific and partner-specific experiences among all members of the network in doing business, transferring technologies and building relational capitals with this recipient or other firms in the same country we suggest,

P1.1 The greater a source network's local knowledge stock, the greater the source organization's teaching capability and thus the more effective the transfer of $R \& D$ capabilities.

Source network's global R\&D knowledge stock

The source network's global R\&D knowledge stock carried by its global R\&D or engineering branches can be seen as a reservoir of R\&D localization experiences, and therefore will also contribute to the teaching capability of the source organization.

P1.2 The greater a source network's global R\&D knowledge stock, the greater the source organization's teaching capability and thus the more effective the transfer of $R \& D$ capabilities.

\subsection{Recipient organization's business network}

In the empirical context of this study, the recipient organization is the Chinese partner of the IJV. A recipient organization's business network (hereafter referred to as "recipient network") is

firm.

${ }^{5}$ If the firms in the host country exhibit a high level of heterogeneity in managerial and learning styles, then the source network's knowledge stock concerning this particular recipient will become more important than its stock of the local knowledge about the host country in general. 
defined as the recipient organization's business network, which consists of the parent or core firm and all subsidiaries of the recipient organization. Recipient networks are also commonly referred to as the Chinese business groups $\mathrm{b}^{6}$. The recipient organization can be either core firm, or subsidiary.

For each IJV we have observed in the field, there is a technology transfer agreement, which strictly restricting the recipient of the technology from further spreading the technology to its Chinese parent firms or other members of the recipient network. Obviously recipient networks are not the recipients of the MNE partner's capability transfer. However, it is still important to study recipient networks in the capability transfer process, since they can imposes influences over the recipient organization in two ways. First, a recipient network can significantly influence the initial knowledge stock of the recipient organization through appointing key managerial personnel and massive transfer of employees ${ }^{\text {}}$, which may imply the transfer of a well-preserved set of routines carried by those managers and employees. The initial endowment of routines and experiences has great significance in the recipient's absorptive capacity and core rigidity. Second, a recipient network can influence the recipient organization in an on-going manner through informal personal ties, personnel rotation and knowledge sharing routines among all units within the recipient network. Therefore, we include recipient networks in this study and consider a recipient as a member of the business group of the Chinese parent firm.

\footnotetext{
${ }^{6}$ Most Chinese auto firms are involved in business groups. Keister (98) provides a good description of Chinese business groups.

${ }^{7}$ According to the Chinese law of joint venture contract, some key positions must be taken by Chinese appointed by the Chinese parent firm.
} 
Recipient network's stock of previous $R \& D$ experiences - Core rigidity or absorptive capacity?

Given that a recipient network affects the initial endowment of $R \& D$ routines through $R \& D$ personnel transfer, the learning capability of the recipient organization will be influenced by the recipient network's previous R\&D knowledge stock. This effect will be moderated by he way, in which the R\&D personnel get transferred from the recipient network to the IJV.

There have been two popular notions about the effect of previous group-embedded knowledge stock on firms' capability to learn. The first notion is that the previous knowledge stock serves as absorptive capacity and enables the possessing firm to learn new knowledge more effectively if the new knowledge can be built incrementally on the previous knowledge stock (Cohen and Levinthal 1990). The second notion is that the previous group-embedded knowledge stock acts as core rigidity or competence trap, which impedes the firm from learning new knowledge, when the environment changes disruptively and renders the previous knowledge stock obsolete (Baum and Ingram 1998; Leonard-Barton 1992; Levitt and March 1988). Group-embedded knowledge of the organization, although can be modified incrementally, is very difficult to be changed in a disruptive manner. Existing tacit routines (or collective knowledge), when in conflict with routines to be acquired, can become core rigidities - "Values, skills, managerial systems, and technical systems that served the company well in the past and may still be wholly appropriate fro some projects or parts of projects, are experienced by other s as core rigidities - inappropriate sets of knowledge." (Leonard-Barton 1992: 118)

These two notions only evaluate the effect the initial group-embedded knowledge on the recipient's capability to learn. We also need to consider the previous technical and managerial experiences carries by individuals. These experiences form individual absorptive capacity and can help the recipient organization to learn more effectively even when the environment changes disruptively and the group-embedded routines have become core rigidity. This is because 
individual knowledge and vision is much less inertial than the group-embedded knowledge and vision in the time of disruptive change. In general, when facing a disruptive change, existing groupembedded routines/capabilities act negatively to the transfer of new routines/capabilities, whereas preexisting knowledge set carried individually can help the acquisition of new knowledge and new routines.

As we discussed in section $2, \mathrm{R} \& \mathrm{D}$ routines, as collective knowledge, is carried by a knowledge group, therefore, they can be disrupted or eliminated when the knowledge group is drastically disrupted. Levitt and March (1988: 328) sited a study by Sproull et al (1978), which indicates when the number of new members in a group is large, the old routines will not conserved. This indicates that empirically, when the recipient organization hiring R\&D personnel from its business network, it can take advantage of the individual absorptive capacity of the experienced personnel, yet avoid importing undesirable routines (which act as core rigidity against the acquisition of the new routines) by avoiding the transfer of the knowledge group of these undesirable routines through large-scale organizational replication or transplantation.

In the context of IJVs in China's auto industry, almost all recipient networks' R\&D routines are old-fashioned and inefficient. Therefore, if got transferred to the IJV's R\&D units, these routines will act as core rigidities and affect negatively on the acquisition of new R\&D routines from the MNE partner. If the recipient organization can manage to import the individual absorptive capacity carried by experienced R\&D personnel from the recipient network (knowing their experience may not be up-to-date) without inheriting the core rigidity through transferring the knowledge group of the recipient network's old R\&D routines in an intact way, then the recipient network's previous R\&D stock will affect the effectiveness of R\&D capability transfer of the IJV positively. The logic of this argument is shown in Figure 2. 
************ Figure 2 about here $* * * * * * * * * *$

\section{P2.1 The effect of a recipient network's previous $R \& D$ experience on the recipient} organization's effectiveness of $R \& D$ capability acquisition is moderated by the way in which the recipient network's $R \& D$ personnel get transferred to the recipient organization. If the transfer is done through in a large-scale organizational replication or transplantation, then the effect will be negative; and vise versa.

\section{Recipient network's stock of IJV experiences}

Empirical evidences from my field study show that recipient networks intentionally circulate best practices of doing business with and transferring knowledge from their MNE IJV partners among the members of the recipient network. By defining the recipient network's IJV knowledge stock as total country-specific and partner-specific experiences among all members of the network in doing business, acquiring technologies and building relational capitals with this partner or other MNE partners $[$, we suggest

P2.2 The greater a recipient network's IJV knowledge stock, the higher the recipient organization's learning capability, thus the more effective the transfer of $R \& D$ capabilities.

\footnotetext{
${ }^{8}$ Prior empirical learning studies have identified several types of experiences: (1) operating experience (2) competitive experience, (3) collaborative experience and (4) foreign entry experience. Here, the IJV knowledge stock refers to the collective collaborative and foreign entry experience stock of the source network.
} 


\subsection{Bridge network}

In addition to the intra-firm networks of both source and recipient organizations, the attributes of the inter-partner network at the interface between the source and recipient, which we call the bridge network, also affect the effectiveness of the capability transfer.

The bridge network is defined as a knowledge transfer network consisted of all employees of both source network and recipient organization involved in joint R\&D tasks. The ties of network are the person-to-person, durable, timely and fine-grained knowledge exchange relationships between the personnel of the source network and those of the recipient organization.

In this empirical context, the ties of bridge network include the following types: (1) those between source organization's international service personnel (ISP) and Chinese employees of the IJV. ISP usually take on the boundary spanner's position of the joint R\&D center, bring in the latest good practices and technologies, and have the know-who and authority to call for experts from home knowledge group to help solve the problems arose in local R\&D tasks (2) Those created by short term visits and rotations of experts/managers from the source network who have high information centrality at various units within source network to the recipient organizations. A Chinese manager once mentioned: "behind these ISP and short-term expatiates is a large network of expertise from the source organization". (3) Those created by sending Chinese IJV employees to the core firm or subsidiaries of the source network for on-job training.

The personal network ties between the learning individual and the teaching individual may outlast the time period of their direct interaction. In other words, a learning individual may come back to the IJV after an on-site training at the source organization's home site. But the information can still flow through the personal ties this learning individual has developed during training period with the help of communication tools. 
The bridge network does not only transfer in one direction from the source (usually the MNE) to the recipient, but also in the opposite direction. The MNE expatriates also learn from their local partners and sometimes the parent firm of local partners the tacit and org-embedded knowledge, value, norms of how things works in the recipient site or country, and reduce culture difference improve teaching and incorporate the local knowledge in the adaptation of the R\&D capabilities. The bridge network can also help the experts in the MNE's knowledge group to understand the needs and learning capabilities of the IJV's local employees. It also provides the MNE's employees the knowledge about technological level of the IJV partners. Therefore, the network carries a two-way flow of understanding between the two partner organizations. However, local knowledge flow tends to deplete after a certain period, whereas the technical knowledge flowing from the MNE to its IJV has to be upgraded over a long period of time. The importance of the flow from the Chinese parent firms to the MNE is less enduring than the flow from MNE to the recipient. In this paper, we will only focus on the latter knowledge flow direction in discussing the bridge network.

\section{Intensity of the bridge network}

The network intensity, generally conceptualized as the frequency of interaction among members of the network, can be measured differently depending upon what the research focus of the network effect is. Conventionally, the intensity of an information network refers to the frequency of information exchange through its ties. However, when considering transfers R\&D capabilities or collective knowledge as the focal function of the bridge network, the network intensity should relate to the frequencies of interactions between the transferors and transferees through which the R\&D capabilities get to be developed at the transferees' site. 
There is no isolated act as pure transferring of capability. As theorists have pointed out, collective knowledge content of routines or capabilities are the organizational memories of experiences, and can only be acquired cumulatively through "doing” (Levitt and March 1988; Nelson and Winter 1982). To acquire R\&D capabilities, the recipient needs to perform tasks that carry direct economic purposes, such as developing a new product or modify an existing design. When performing these tasks, experiences for coordinating different knowledge ingredients are developed through either unintentional trial and error or intentional searching and teaching, and then through the organizational interpretation system, some of these experiences get routinized and become capabilities of the recipient (Levitt and March 1988). Therefore, transferring R\&D capabilities is in fact a process of exposing the recipient to $\mathrm{R} \& \mathrm{D}$ tasks, and allowing the recipient to accumulate the knowledge coordination/recombination experiences and store these experiences into a collective memory of how to perform these tasks effectively and efficiently, which is the core of R\&D capabilities. Without $R \& D$ tasks for the recipient to practice, there is no way that $R \& D$ capabilities can get transferred.

In addition to the requirement of the availability of $R \& D$ tasks for the recipients, there is also a requirement for how these tasks should be carried out. In order to enable the tacit-to-tacit transfer of R\&D experiences, substantial interactions between the source and the recipient firms is essential, and apprenticeship must be developed (Nonaka and Takeuchi 1995; Polanyi 1962). Therefore to effectively transfer R\&D capabilities, sufficient amount of R\&D tasks must be performed jointly between the learner and the teacher. The intensity of the bridge network can be reflected by the number of R\&D tasks performed jointly by the source and the recipient organizations.

\footnotetext{
P3.1 The greater the intensity of a bridge network the more effective the $R \& D$ capability transfer.
} 
It is understandable that at the early stage of acquiring R\&D capabilities, the recipient will not be entrusted with full-blown R\&D projects for real market purposes, even with the assistance of expatriates from the source firm. In the auto industry, R\&D projects involve many different levels of difficulty. The most extensive R\&D activity is the development of a new platform, which includes styling, redesign of power train and key subassemblies and components. This kind of projects usually cost more than a billion dollars for each platform and need production volume exceeding a million vehicles a year to recover the $R \& D$ costs. Obviously, this is not a feasible starting task for the recipient firm to work on. And in reality, the source organizations, usually MNEs from the industrialized countries, have no intention to hand over this kind of activities or capabilities to their partners in LDCs.

The realistic tasks for both the recipient and the source firms lie in the R\&D activities with lower degree of difficulty and narrower scope. Most joint R\&D tasks performed in the Chinese auto sector between local recipients and the multinational source firms limit in recombining local knowledge with the MNE's general knowledge, that is to carry over an existing platform developed by the MNE and modify the style, adjust dimensions and parameters of some components based on local customer taste, driving conditions and government regulations. This type of tasks, though simple, still call for great deal of coordination among functional groups such as: marketing, analysis, design, prototype, validation and production. Engaging in these tasks can expose the recipients to a large portion of $R \& D$ routines and different stages of $R \& D$ process.

The outcome of the joint R\&D tasks therefore are twofold (1) the physical outcome (new product, design modification) (2) the capability outcome (higher R\&D capabilities of the learner) 
The scope of a network usually indicates the array of agents involved in the network. Since in this empirical context, the main purpose of the bridge network is to transfer collective knowledge underlying the R\&D capabilities, the scope of the bridge network should be the reflection of the scope of the teaching and learning groups, which we have discussed in Section 3.2.

The concept of knowledge group is crucial here, because it is the indivisible carrier for certain level of routines. For instance, an engine design team within a R\&D center is a knowledge group, which carries the routines/capabilities to engine design, whereas a platform design unit is a higher-level knowledge group which contains the routines/capabilities to integrate engine, transmission and other subassemblies into a vehicle platform. Within a MNE, all of the R\&D branches of its various subsidiaries form the highest level of R\&D knowledge group. In reality these different levels of knowledge communities are sometimes intertwined through matrix organization design and personnel transfer.

Routine or capability transfer is not an individual-to-individual knowledge flow but a groupto-group knowledge flow. It involves two aspects: Group teaching and group learning.

Group teaching refers to the exposure of the transferees to the knowledge group of the transferors to acquire collective knowledge through participating the group activities in the transferor's knowledge group. Through group teaching, the transferees can observe interactions and coordination routines among different knowledge carriers within the transferors' knowledge group. The tacit, co-specialized and group-embedded routines may span different functional groups and across different R\&D stages, and cannot be acquired by the transferees without the transferees being embedded in the knowledge group and working with the members of the knowledge group. Teaching by individual teacher is a necessary condition for transferring individual knowledge, but not sufficient for transferring the tacit routines or collective knowledge. 
In addition to obtaining tacit, co-specialized and group-embedded technical knowledge, group teaching also enables the transferees to experience the organizational environment and tacitly acquire the values, beliefs and norms of the transferor's knowledge group. This resembles the “socialization” process (Nonaka and Takeuchi 1995).

Bridge network connects the transferees from the recipient organization with a broad teaching group, which consists of the group of the MNE's expatriates sent to the recipient's local site from either the MNE core R\&D unit or subsidiary branches and/or the knowledge group the transferees worked with at either the MNE's core or subsidiary sites during their overseas on-job training.

We only count direct ties (i.e., personal work relations) in the bridge network, since indirect ties can only provide information but not tacit knowledge, especially co-specialized or groupembedded knowledge. By defining the scope of the teaching group as the diversity of the source organization's functional divisions, with which the transferees of recipient organization have worked and gotten their on-job trainings, we suggest

\section{P3.2 The better the scope of a teaching group matches with the scope of the technical and} managerial skills which each $R \& D$ personnel of the recipient organization is intended to acquire, the more effective the $R \& D$ capability transfer.

We do not use the total number of direct ties in the bridge network to predict the effectiveness of R\&D capability transfer, because we believe that it is not the number but the diversity of ties that matters for the transferees to observe and acquire the capabilities.

The final goal of $R \& D$ capability transfer is forming the $R \& D$ related knowledge coordination and collaboration routines among the employees at the recipient's site. The collective 
memory of R\&D experiences must be developed among the transferees by working and learning together as a group. This is what we call Group Learning. Individual learning from the group teaching is critical but is only a necessary condition, not sufficient. The R\&D related experiences gained from the teaching group by individual transferees must then be incorporated in the learning group through collective memory formation process ${ }^{9}$ (Levitt and March 1988).

In an experiment of group training, Liang et al found that training employees in their work groups is more effective than training them individually. The results indicated that group training improved group performance primarily by fostering the development of transactive memory systems among group members, which is a similar concept as the collective memory or collective knowledge (Liang, Moreland and Argote 1995). By defining the scope of the learning group as the scope of interaction in the team learning process among trainees who are expected to gain and carry certain routines as a group, we suggest:

P3.3 The better the scope of the learning group matches with the scope of the technical and managerial skills needed for performing the desired $R \& D$ tasks, the more effective the $R \& D$ capability transfer.

\section{IT infrastructure}

\footnotetext{
${ }^{9}$ Transferring R\&D capabilities from one firm to the other appears similar to on-job training of new hires, but in fact has fundamental differences (1) transferring R\&D capabilities entails a learning group not just learning individuals (2) new hires are inherited with the existing operational context, whereas R\&D capability recipients are expected to develop a new operational environment alongside with their learning process.
} 
Electronic means of communication is an important component of the bridge network, because it enables long-distance and timely communication between any pair transferor and transferee. Nonetheless, IT infrastructure is more effective at transferring knowledge when participants already have communication relationship established through direct contacts than establishing new communication relations (Argote and Ingram 2000). In other words, direct ties are the foundations of the effective usage of the IT infrastructure, and therefore cannot substituted by the IT infrastructure when transferring knowledge, especially the tacit part of knowledge. IT infrastructure also allows group-to-group communication through tele-conferences. Therefore, some non-tacit but group-embedded knowledge can also be transferred through IT infrastructure.

P3.4 The more effective the IT infrastructure within a bridge network, the more effective $R \& D$ capability transfer.

\section{Formal training}

Although the core component of $R \& D$ capabilities is collective knowledge, part of R\&D capabilities is codified into written documents and has been widely spread in the public domain. The latter part of R\&D capabilities includes fundamental technical and R\&D managerial knowledge that every R\&D personnel should equip before they engage in R\&D tasks. Every major auto MNE has developed a codified system of $\mathrm{R} \& \mathrm{D}$ project management over the years. It is important to transfer these codified knowledge system to the transferees in a formal setting. Formal training is effective in improving technical and managerial literacy of the personnel of the recipient organization, and thereby increasing their absorptive capacity in the R\&D capability transfer process. 
P3.5 The greater the portion of a recipient organization's $R \& D$ personnel that have received formal trainings in technical and managerial knowledge related to their $R \& D$ projects, the more effective the $R \& D$ capability transfer

In summary, the transfer of R\&D capabilities is an effort involving not just the stylized single-channel and discrete knowledge flow between the source and the recipient organizations, but a lasting web of direct ties between the personnel of the source network and the personnel of the recipient organization. Capabilities or routines must be acquired through group teaching, group learning and learning by doing. A bridge network provides the mechanisms that can satisfy the following requirement if designed properly. Other supplementary capability transfer mechanisms such as IT infrastructure and formal training can enhance the direct ties of a bridge network, yet are not capable of substituting them.

Furthermore, the effective R\&D capability transfer does not only depend on the attributes of the source and recipient organizations, but also depends on the local knowledge stock and the global R\&D knowledge stock of the source network, the IJV and R\&D knowledge stock of the recipient network, and the initial endowment of $R \& D$ routines of the recipient organization. The possible logical linkages between network-related factors and the effectiveness of the R\&D capability transfer are shown in Figure 3.

***************** Figure 3 about here $* * * * * * * * * * * * * *$

\section{Empirical context and methodology}

\subsection{Empirical context}


The activities of transferring R\&D capabilities in Chinese auto industry is selected as the empirical setting for this study because (1) there are growing evidences of MNE's transferring R\&D capability to their joint ventures in this industry, and (2) there are significant technological, cultural and managerial distance between the source organizations, which are foreign MNEs, and the recipient organizations, which are the IJVs of the MNEs in this industry. This large asymmetry between the two alliance partners indicates a greater level of inter-partner learning (Dussauge, Garrette and Mitchell 2000), and therefore provides a natural setting for studying how firms apply their network knowledge stock and design their inter-partner network structure to overcome the transfer difficulties and achieve effective capability transfer.

When China's auto industry opened to foreign investors in the early 1980's, its R\&D capability in passenger car sector is almost zero. Most state owned enterprises (SOEs) in this sector were initially formed to produce commercial vehicles not passenger ones. These enterprises were characterized by low R\&D effort (R\&D spending is less than $1 \%$, across the board, far lower than those of MNEs) and long platform upgrade cycles (usually longer than 20 years).

Auto industry is a considered a pillar industry by the Chinese government. The industrial policy gives strong emphasis on developing indigenous $R \& D$ capabilities. The approval guidelines for foreign MNEs' to establish IJVs in the Chinese auto industry involves provisions such as (1) the IJV must have a internal technical center, which is capable for the developing future generations of products, and (2) the products of the IJV must reach the global technological level of the 90's (The State Administration of Machinery Industry 1995). The industrial policy makers of this industry also gave strategic guidelines for developing indigenous R\&D capabilities, such as (1) vehicle OEMs should take $5 \%$ to $10 \%$ of total reinvestment into developing or expanding their tech centers (2) R\&D spending over sales should reach 2 to $3 \%$ (now it is less than $1 \%$ among all SOEs), and (3) key component suppliers should apply $10 \%$ to $20 \%$ of their reinvestment to set up their own 
R\&D facility or tech centers. The government also provides financial and taxation support for joint R\&D projects among business groups (The State Administration of Machinery Industry 1995).

MNEs have seen the potential of the emerging car market in China since the early 80's. AMC-Jeep and VW were the first 2 MNEs entered China. They entered with cautious attitude about the industrial infrastructure and local market, therefore only brought in CKD with low local content and near-to-zero local knowledge content. The big commercial success of VW in the late 80's and early 90's evoked a stride of inflow of foreign investment in both vehicle OEM and supplier sectors. In order to earn the approval of entering China, MNEs must make commitment to bring in the latest product/process technologies and help develop the indigenous R\&D capabilities at their local operations.

China's demand for R\&D capability transfer does not necessarily contradict with the longterm vision of MNE investors. As the competitions in the host country's market becomes more and more global and intense, new products that suits the local taste and regulations need to be developed at a faster pace. Transferring the R\&D capabilities to the operations close to the market then becomes more beneficial (Buckley and Casson 1976). MNEs’ R\&D activities in the LDCs are mostly at the end stage of the R\&D cycle, with the tasks such as adapting the general design to the

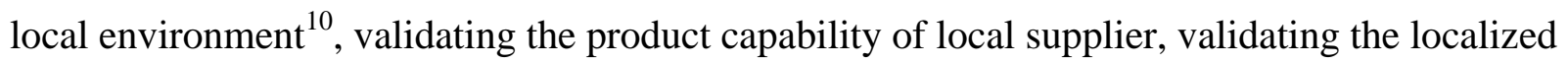
product design to meet the quality, safety and environmental requirements.

\footnotetext{
${ }^{10}$ The design adaptation/localization process takes varying degree of local knowledge content, ranging from extending the length of the car to re-design the exterior and interior and fitting a new engine. GM-Shanghai, for example, made 600 engineering changes to tailor the Buick Century to Chinese driving conditions and regulations. For instance, the rear seat is elevated, legroom in the back has been enhanced and the suspension has been fine-tuned for China's road conditions.
} 


\subsection{Methodology}

A qualitative approach is used for this study. Semi-structured and open-ended interviews based on a preliminary framework was conducted with interviewees from four IJVs in Chinese auto industry, which all have on-going R\&D capability transfer programs. We interviewed more than 2 persons in each IJV, with each interview last at least 2 hours. Field observations were also conducted at the joint R\&D centers and manufacturing plants of these four IJVs. Documents with regard to these IJVs' strategies, structures, activities and performances were collected. The initial theoretical framework was refined as the study proceeded.

The rationale for using qualitative approach lies in the following aspects: First, the intent of this study is to explore new theoretical ground rather than to test existing frameworks. Second, the propositions of this paper deal with detailed firm-specific constructs that cannot easily be obtained and analyzed with quantitative methods (Rouse and Daellenbach 1999; Strauss and Corbin 1990; Yin 1981; Capron and Mitchell 1999).

\section{Results}

The results of the interviews, discussions and field observations are outlined in Table 1. It should be noted that this study was done at the initial stage of the R\&D capability transfer projects undertaken by the sample IJVs. Therefore, the results reveal more about the strategic choice of mechanisms by the parties involved in the transfer projects in managing the transfer process than about the evaluation of the effectiveness of these strategies and mechanisms. Since transfer of R\&D capability is a time-consuming process, it will take several years before we can finally judge the effectiveness of these strategies and mechanisms. Given these limitations of the results, the results 
are still important in that they provide evidences for the face validity of the propositions derived from theories. The observations of strategic choices of the parties in this study reflect the perceived effectiveness by the practitioners based on their past experiences of the initial stage of the current transfer project and other similar transfer projects. The actual effectiveness, which is the overall evaluation of the effectiveness, however, will be judged at the later stage of the R\&D capability transfer process. Since the perceived effectiveness and actual effectiveness are likely to be correlated, the current results, which reflects the perceived effectiveness will provide support to the validity of the propositions, which predict the actual effectives.

$* * * * * * * * *$ Table 1 about here $* * * * * * * * * *$

In many cases listed in the table, the parties involved in the $R \& D$ transfer projects used the strategies or mechanisms that are predicted to be effective according to the propositions of this paper. In general, the validity of all the propositions is supported.

\section{Concluding points}

This paper applies network lenses to look at the process of knowledge transfer from a broader scope rather than from the perspectives of individual source and recipient organizations. The theoretical contributions of this paper lies in the following three areas: First, we systematically identified three networks that are involved in the R\&D capability transfer process, namely recipient network, source network and bridge network. Second, we specified various network measures that relate to the effectiveness of $R \& D$ capability transfer between a source organization and a recipient organization. And lastly, we predicted the impact of these measures of these networks on 
effectiveness of the R\&D capability transfer, based on the theoretical analysis of the requirements for transferring $R \& D$ capabilities.

We found two general aspects of networks - network knowledge stock and network structure - contribute to the effectiveness of R\&D capability transfer. The network knowledge stock of a recipient network can affect the recipient organization's learning capability, whereas the network knowledge stock of a source network can affect the source organization's teaching capability. The network knowledge stocks of both partners of an IJV serve to attenuate the cultural and managerial incompatibility and technological gap between them. We partitioned network knowledge stock into a two-by-two taxonomy along two dimensions - technical (or R\&D) vs. alliance/local and recipient side vs. source side (see Table 2).

$* * * * * * * * * *$ Table 2 about here $* * * * * * * * * * *$

We argued that both technical and alliance/local knowledge of the business network of a source organization help it to transfer R\&D capability more effectively. However, the effect of the knowledge stock of a recipient organization is not as straightforward. Though the alliance knowledge stock of the network of a recipient can improve the recipient's learning capability, given that the R\&D knowledge stock of a recipient network is obsolete comparing with the R\&D knowledge to be transferred from the source organization, this type of knowledge stock has a mixed effect on the recipient's learning capability. The moderating factor that determines the sign of this effect is the extent to which the recipient organization replicates or inherits the R\&D organization of the recipient network. Based on the distinction between the positive effect of the individual absorptive capacity of experienced $R \& D$ personnel from the recipient network and the negative effect of the core rigidity embedded among the knowledge groups of the R\&D units of the recipient 
network, we argue that if a recipient network endows the recipient organization with its core rigidity through large-scale organizational replication, then the recipient organization will encounter more learning cost for unlearning the old routines. In other words, although individual R\&D personnel from the recipient network bring in individual absorptive capacity to the recipient organization, as an undisrupted knowledge group embedded with old R\&D routines, they carry a highly inertial resistance to the acquisition and implementation of the new R\&D routines. In summary, a network knowledge stock has potential either to enhance or hamper R\&D capability transfer, depending up the nature of the stock and some moderating effects.

The second general aspect of network we discussed is network structure. The network structure measures to which we paid most attention is the intensity and scope of the bridge network, which is the interface between a recipient and a source organization. The intensity of a bridge network, as measured by the number of jointly performed R\&D tasks, manifests the learning-bydoing and learning-by-direct contact requirements for transferring tacit knowledge. On the other hand, the scope of a bridge network reflects the group-to-group nature of transferring embedded knowledge. Since the core content of R\&D capabilities is the knowledge that is both tacit and embedded, the intensity and the scope of a bridge network are both critical measures for the effectiveness of R\&D capability transfer.

There are two theoretical arguments that we think are most novel in this paper. First, we argue that group teaching and group learning mechanisms are more effective in transferring embedded and tacit knowledge than individual teaching and individual learning mechanisms. Second, we believe that past technical experience of the recipient organization has both positive and negative implications to the effectiveness of its acquisition of new embedded and tacit knowledge. The prior technical experience of individual persons serves as absorptive capacity and positively relates to the effectiveness of the $R \& D$ capability transfer, whereas the prior routines embedded in 
the knowledge groups of the recipient organization act as core rigidity and thus negatively relate to the effectiveness of R\&D capability transfer.

The key empirical implications of this study are as following: (1) Practitioners need to realize that the $R \& D$ capabilities can only be transferred through performing $R \& D$ tasks. And the transfer will be more effective if these tasks are performed jointly by personnel from both sides of the transfer. IT and formal training, although important, cannot replace the learning from performing R\&D tasks. (2) It is important that the managers and engineers of the recipient organization learn as a group from the entire knowledge group of the source organization. This usually implies sending a group of engineers from the recipient site to the source site and performing joint R\&D tasks. (3) The absorptive capacity of the recipient organization can be enhanced by hiring experienced individuals from the R\&D units of the recipient network. However the recipient organization should avoid replicating or adopting the entire $R \& D$ units from its network, which are usually characterized by obsolete $R \& D$ routines.

As an exploratory study, this paper has the following imitations: (1) Data are collected at the early stage of the R\&D capability transfer process. Therefore, the propositions cannot be fully tested. Only the validity of these propositions is confirmed by the initial field data. (2) The sample size of this study is limited.

The future extension of this study will be carried out following these steps: (1) We will refine the propositions and develop testable hypotheses. (2) We will design survey instrument and perform a large-scale survey at a more matured stage of the R\&D capability transfer process. (3) An additional study focusing on the teaching intent and protection scheme of the source organizations will also be pursued.

\section{Acknowledgements}


We thank William Davidson Institute for research and funding support for this study, and Joanne Oxley for her suggestions and comments. Zheng Zhao also thanks numerous interviewees from different organizations both in China and in the U.S. for their assistances and insights. 


\section{References}

1. Ahuja, Gautam, 1996, Collaboration Networks, Structural Holes, and Innovation: A Longitudinal Study, The University of Texas at Austin.

2. Amit, Raphael, and Paul J. H. Schoemaker, 1993, Strategic Assets and Organizational Rent, Strategic Management Journal 14,33-46.

3. Anand, Bharat N., and Tarun Khanna, 2000, Do firms learn to create value? The case of alliance. Strategic Management Journal 21,295-315.

4. Anand, Jaideep, 2000, Fungibility and context-specificity of capabilities and the international expansion of firms, working paper.

5. Argote, Linda, and Paul Ingram, 2000, Knowledge Transfer: A basis for competitive advantage in firms. Manuscript.

6. Argyris, C., and D.A. Schon, 1978, Organizational learning (Addison-Wesley, Reading, MA)

7. Baranson, Jack, 1977, International transfer of automotive technology to developing countries, United nations institute for training and research UNITAR research report No.8.

8. Baum, Joel A.C., and Paul Ingram, 1998, Survival-enhancing learning in the Manhattan hotel industry, 1898-1980, Management Science 44,996-1016.

9. Buckley, Peter J., and Mark Christopher Casson, 1976, Chapter 2. A long-run theory of the multinational enterprise, in: The future of the multinational enterprise (Holms \& Meier, London)

10. Burt, Ronald S., 1992, Networks and Organizations: Structure, Form and Action (Harvard University Press, Cambridge, Massachusetts, and London, England) 
11. Capron, Laurence, and Will Mitchell, 1999, The impact of relevant resources and market failure on four modes of business change: A conceptual framework with examples from the corporate client segment of the information communication technology business, working paper.

12. Cohen, Wesley M., and Daniel A. Levinthal, 1990, Absorptive Capacity: A New Perspective On Learning And Innovation, Administrative Science Quarterly 35,128-153.

13. Dierickx, Ingemar, and Karel Cool, 1989, Asset Stock Accumulation and Sustainability of Competitive Advantage, Management Science 35,1505-1513.

14. Dunning, John H., 1988, The eclectic paradigm of international production: a restatement and some possible extensions, Journal of International Business Studies, Spring Issue, 1-29.

15. Dussauge, Pierre, Bernard Garrette, and Will Mitchell, 2000, Learning from competing partners: outcomes and durations of scale and link alliances in Europe, North America and Asia, Strategic Management Journal 21,99-126.

16. Fiol, C. Marlene, and Marjorie A. Lyles, 1985, Organizational learning, Academy of Management Review 10,803-13.

17. Granovetter, Mark, 1985, Economic action and social structure: the problem of embeddedness, American Journal of Sociology 91, 481-510.

18. Grant, Robert M., and Charles Baden-Fuller, 1995, A knowledge-based theory of inter-firm collaboration, Academy of Management Best Paper Proceedings, 17-21.

19. Gulati, Ranjay, 1998, Alliance and networks, Strategic Management Journal 19,293-317.

20. Gupta, A.K., and V. Govindarajan, 2000, Knowledge flows within multinational corporations, Strategic Management Journal 21,455-472.

21. Hannan, Michael T., and John Freeman, 1989, Organizational Ecology (Harvard University Press, Cambridge, Massachusetts, and London, England) 
22. Henderson, Rebecca M., and Clark, Kim B., 1990, Architectural innovation: the reconfiguration of existing product technologies and the failure of established firms, Administrative Science Quarterly, 35, 9-30.

23. Henderson, Rebecca M., and Cockburn, Iain, 1994, Measuring competence? Exploring firm effects in pharmaceutical research, Strategic Management Journal, 15, 63-84.

24. Hennart, Jean-Francois, 1988, A transaction costs theory of equity joint ventures, Strategic Management Journal 9,361-374.

25. Hymer, Stephen H, 1976, The international operations of national firms: a study of direct foreign investment (MIT Press, Cambridge, MA)

26. Johanson, J, and J-E Vahlne, 1977, The internationalization process of the firm - A model of knowledge development and increasing foreign market commitments, Journal of International Business Studies 8, 23-32.

27. Kogut, Bruce, and Harbir Singh, 1988, The effect of national culture on the choice of entry mode, Journal of International Business Studies 19,411-32.

28. Kogut, Bruce, and Udo Zander, 1992, Knowledge of the Firm, Combinative Capabilities, and the Replication of Technology. Organization Science 3, 383-397.

29. Kogut, Bruce, and Udo Zander, 1993, Knowledge of the firm and the evolutionary theory of the multinational corporation, Journal of International Business Studies 24, 625-645.

30. Leonard-Barton, Dorothy, 1992, Core Capabilities and Core Rigidities: A Paradox in Managing New Product Development, Strategic Management Journal 13,111-126.

31. Levitt, Barbara, and James March, 1988, Organizational Learning, Annual Review of Sociology 14,319-40. 
32. Liang, Diane Wei, Richard Moreland, and Linda Argote, 1995, Group versus individual training and group performance: The mediating role of transactive memory, Personality and Social Psychology Bulletin 21,384-393.

33. Luo, Yadong, and Mike W. Peng, 1999, Learning to compete in a transition economy: Experience, environment, and performance, Journal of International Business Studies $30,269-296$.

34. Nelson, Richard R., and Sidney Winter, 1982, An Evolutionary Theory of Economic Change (Harvard University Press, Cambridge, Massachusetts, and London, England)

35. Nonaka, Ikujiro, and Hirotaka Takeuchi, 1995, The knowledge-creating company: How Japanese companies create the dynamics of innovation (Oxford University Press, New York, Oxford)

36. Pavitt, Keith, 1990, What we know about the strategic management of technology, California Management Review, 32, 17-26

37. Penrose, Edith, 1959, The Growth of the Firm (M. E. Sharpe, Inc., White Plains, New York)

38. Polanyi, Michael, 1962, Chapter 4: Skills. Personal knowledge (Harper and Row, New York)

39. Powell, Walter, Kenneth Koput, and Laurel Smith-Doerr, 1996, Interorganizational collaboration and the locus of innovation: networks of learning in biotechnology, Administrative Science Quarterly 41, 116-145.

40. Prahalad, C. K., and Gary Hamel, 1990, The Core Competence of the Corporation, Harvard Business Review 68,79-91.

41. Rouse, Michael J., and Urs S. Daellenbach, 1999, Rethinking research methods for the resource-based perspective: isolating sources of sustainable competitive advantage, Strategic Management Journal 20,487-494. 
42. Schumpeter, Joseph Alois, 1934, The Theory of Economic Development (Harvard University Press, Cambridge, Massachusetts, and London, England)

43. Selznick, Philip, 1957, Leadership in Administration (Harper and Row, New York)

44. Spender, J.C., 1996, Making knowledge the basis of a dynamic theory of the firm, Strategic Management Journal 17,45-62.

45. Strauss, Anselm, and Juliet Corbin, 1990, Basics of Qualitative Research (Sage Publications, New Park, London, and New Delhi)

46. Szulanski, Gabriel, 1996, Exploring internal stickiness: Impediments to the transfer of best practice within the firm, Strategic Management Journal 17,27-43.

47. Teece, David J., 1986, Transaction cost economics and the multinational enterprise: An assessment, Journal of Economic Behavior and Organization, 21-45.

48. The State Administration of Machinery Industry, P.R. China, 1995, Policies about China automotive industry (SAMI, Beijing)

49. Uzzi, Brian, 1997, Social structure and competition in interfirm networks: the paradox of embeddedness, Administrative Science Quarterly 42,35-67.

50. Williamson, Oliver E, 1981, The modern corporation: Origins, evolution, and attributes, Journal of Economic Literature 19,1537-68.

51. Yin, Robert K, 1981, The case study crisis: Some answers, Administrative Science Quarterly 26,58-65. 


\section{Tables}

Table 1. Results: (For the coding scheme of the interviewees, see the Note at the end of this table)

\begin{tabular}{|c|c|c|}
\hline Propositions & 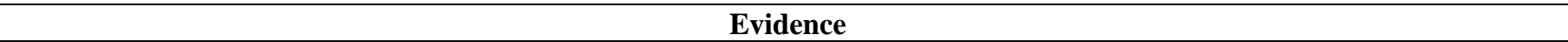 & Inferences \\
\hline P1.1 & $\begin{array}{l}\text { A-FP-1 talked about the source network of the IJV "A": "Best practices are frequently communicated among subsidiaries. For } \\
\text { example, when establishing the R\&D project in our Chinese IJV, we got help from our Australian subsidiary's product expertise } \\
\text { and Polish subsidiary's expertise in managing IJVs in the transition economies." When asked about the mechanisms used for the } \\
\text { inter-subsidiary communication A-FP-1 mentioned the following } \\
\text { - Regularly use of IT, such as: multimedia conference, data-exchange, e-mail } \\
\text { - Personnel visit, exchange and rotation } \\
\text { - Higher level managers' monetary incentive being linked to global growth } \\
\text { - Leadership vision in global operations } \\
\text { - Rersonal relationships and informal contacts among leaders of different subsidiaries } \\
\text { - Internal newsletters and documents } \\
\text { Most IJVs that were interviewed take advantage of the source network's global (especially LDC) operation experiences in the } \\
\text { similar way mentioned in the evidence. }\end{array}$ & $\begin{array}{l}\text { Validity } \\
\text { supported }\end{array}$ \\
\hline P1.2 & $\begin{array}{l}\text { A-CP-1: "Our foreign partner's R\&D branches in Brazil and Australia were heavily involved in the R\&D capability } \\
\text { development here. They've provided assistance with their expertise in transferring and localizing technologies. When we were } \\
\text { developing our first passenger car model, our foreign partner's Australia R\&D branch sent several exterior designers and } \\
\text { modeling engineers to here and gave us hands-on trainings." } \\
\text { IJV "B”, which has R\&D branches in the LDCs also made use of the R\&D experience of that branch in its Chinese R\&D } \\
\text { project. }\end{array}$ & $\begin{array}{l}\text { Validity } \\
\text { supported }\end{array}$ \\
\hline P2.1 & $\begin{array}{l}\text { B-CP-2: "A lot of our engineers are from the tech center of our Chinese parent firm. When they were in the tech center, they } \\
\text { could not achieve any meaning new design. Now, with new organization and advanced management, they developed a new car } \\
\text { model based on a advanced chassis system from our foreign partner in only one year." } \\
\text { C-CP-1: "Transforming an old R\&D unit is much difficult than starting a new one from scratch." } \\
\text { A-CP-1: "We have been trying to attract high quality personnel from top-notch universities and other companies to work for us, } \\
\text { with high salary and working conditions." }\end{array}$ & $\begin{array}{l}\text { Validity } \\
\text { supported }\end{array}$ \\
\hline
\end{tabular}




\begin{tabular}{|c|c|c|}
\hline P2.2 & $\begin{array}{l}\text { A-FP-3 compared the transfer performance between two Chinese partners of A-FP: "[Chinese Partner I] was much more } \\
\text { experienced and easier to cope with than [Chinese Partner II]... This difference is due to the fact that [Partner I] has had a lot } \\
\text { more IJV experience and their managers, engineers and workers understand better about the advanced technologies, managerial } \\
\text { procedures, quality standards, and the proper way to interact with us." } \\
\text { B-CP-1: "When [IJV "B"] was established, some experienced managers were transferred from the other IJV [B-CP's] to here } \\
\text { per [B-CP's] request. And you bet that was a great support for us." }\end{array}$ & $\begin{array}{l}\text { Validity } \\
\text { supported }\end{array}$ \\
\hline P3.1 & $\begin{array}{l}\text { D-CP-1: "It took us } 12 \text { years of learning period before we gain adequate R\&D capability to design our own vehicle. We } \\
\text { experienced } 5 \text { rounds of the failed formal R\&D trials before it finally succeeded. All the R\&D projects were performed jointly } \\
\text { with our foreign partner either in their site or here." } \\
\text { C-CP-2: "We tried very hard to win the bid for a face-lifting project for a compact passenger car in order to gain R\&D } \\
\text { experiences. The tuition is quite worthwhile" }\end{array}$ & $\begin{array}{l}\text { Validity } \\
\text { supported }\end{array}$ \\
\hline P3.2 & $\begin{array}{l}\text { B-CP-1 who went through an extensive on-job training in the B-FP's site mentioned: "I did not realize how many knowledge I } \\
\text { had missed at home until I came here and worked with many engineers from different department. Learning from the whole } \\
\text { system is far more effective than learning from a few individual experts. The most effective way to learn how things can } \\
\text { actually get done is to work with different people in different functional groups that are involved in the project. You need to see } \\
\text { how each job element is done by individual engineers or groups as well as how they coordinate those job elements." }\end{array}$ & $\begin{array}{l}\text { Validity } \\
\text { supported }\end{array}$ \\
\hline P3.3 & $\begin{array}{l}\text { B-FP-1: "In order to cultivate [our Chinese JV's] indigenous R\&D capabilities, we've sent } 40 \text { Chinese engineers responsible for } \\
\text { different R\&D functions to Germany for on-job training throughout the entire process of vehicle development. The trainees } \\
\text { engaged in a six-month study of their own specialty in a German university, and then transferred to [our company's] vehicle } \\
\text { development center to receive on-job training and participated in development projects, which include vehicle platform } \\
\text { arrangement, styling, and component design using computer-aided vehicle design systems. These Chinese engineers interact } \\
\text { with each other during the learning process. They came home working together on same types of tasks as a cohort." }\end{array}$ & $\begin{array}{l}\text { Validity } \\
\text { supported }\end{array}$ \\
\hline P3.4 & $\begin{array}{l}\text { A-FP-1: "IT is important in technology transfer. Lot of communications between our headquarter and the [Chinese IJV] are } \\
\text { done through IT. We have been working on the CAD/CAE software and IT protocol compatibility with all of our global R\&D } \\
\text { operations. Our goal is to establish a global-engineering system with all R\&D branches around the world and be able to } \\
\text { leverage the global engineering capacity and perform joint R\&D around the clock." }\end{array}$ & $\begin{array}{l}\text { Validity } \\
\text { supported }\end{array}$ \\
\hline P3.5 & $\begin{array}{l}\text { B-CP-2: "We've sent many of our Chinese engineers and mangers of to [an independent training center] that teaches technical } \\
\text { and project management courses. Some of them complained that the training courses in project management only give them } \\
\text { some basics and couldn't solve their particular problems. But in general, these courses have been helpful in providing the basics. } \\
\text { We will continue to do this" } \\
\text { According to our interview with the manager of the above-mentioned training center, many other IJVs have sent their Chinese } \\
\text { employees for formal training, in order to improve their technical and managerial literacy. }\end{array}$ & $\begin{array}{l}\text { Validity } \\
\text { supported }\end{array}$ \\
\hline
\end{tabular}

Note: The interviewees are labeled for confidentiality purpose. The first letter of the code stands for the IJV which the interviewee is from; the second and third letters tell whether the interviewee is from the Chinese partner side (CP) or from the foreign partner side (FP); and the number at the end of a code stands for rank order of this interviewee being interviewed in its work area. For example, the code "A-FP-1" stands for the first interviewee from the foreign partner (FP) of the IJV "A". The code "C-CP-2" stands for the second interviewee from the Chinese partner (CP) of the IJV "C". 
Table 2. The predicted effects of various network knowledge stocks on the recipient organization's learning capability and the source organization's teaching capability

\begin{tabular}{|l|l|l|}
\hline Type & Technical (or R\&D) Knowledge Stock & Alliance/Local Knowledge Stock \\
\hline Recipient Network & $\begin{array}{l}\text { (Proposition 2.1) } \\
\text { Mixed effect on a recipient organization's learning } \\
\text { capability. Moderated by the extent of } \\
\text { organizational replication between the recipient } \\
\text { network's and the recipient organization's R\&D } \\
\text { units. }\end{array}$ & $\begin{array}{l}\text { Positive effect on a recipient organization's } \\
\text { learning capability. }\end{array}$ \\
\hline Source Network & $\begin{array}{l}\text { (Proposition 1.2) } \\
\text { Positive effect on a source organization's teaching } \\
\text { capability. }\end{array}$ & $\begin{array}{l}\text { Positive effect on a source organization's } \\
\text { teaching capability. }\end{array}$ \\
\hline
\end{tabular}


FIGURES:

Figure 1. Diagram of the three networks involved in R\&D capability transfer

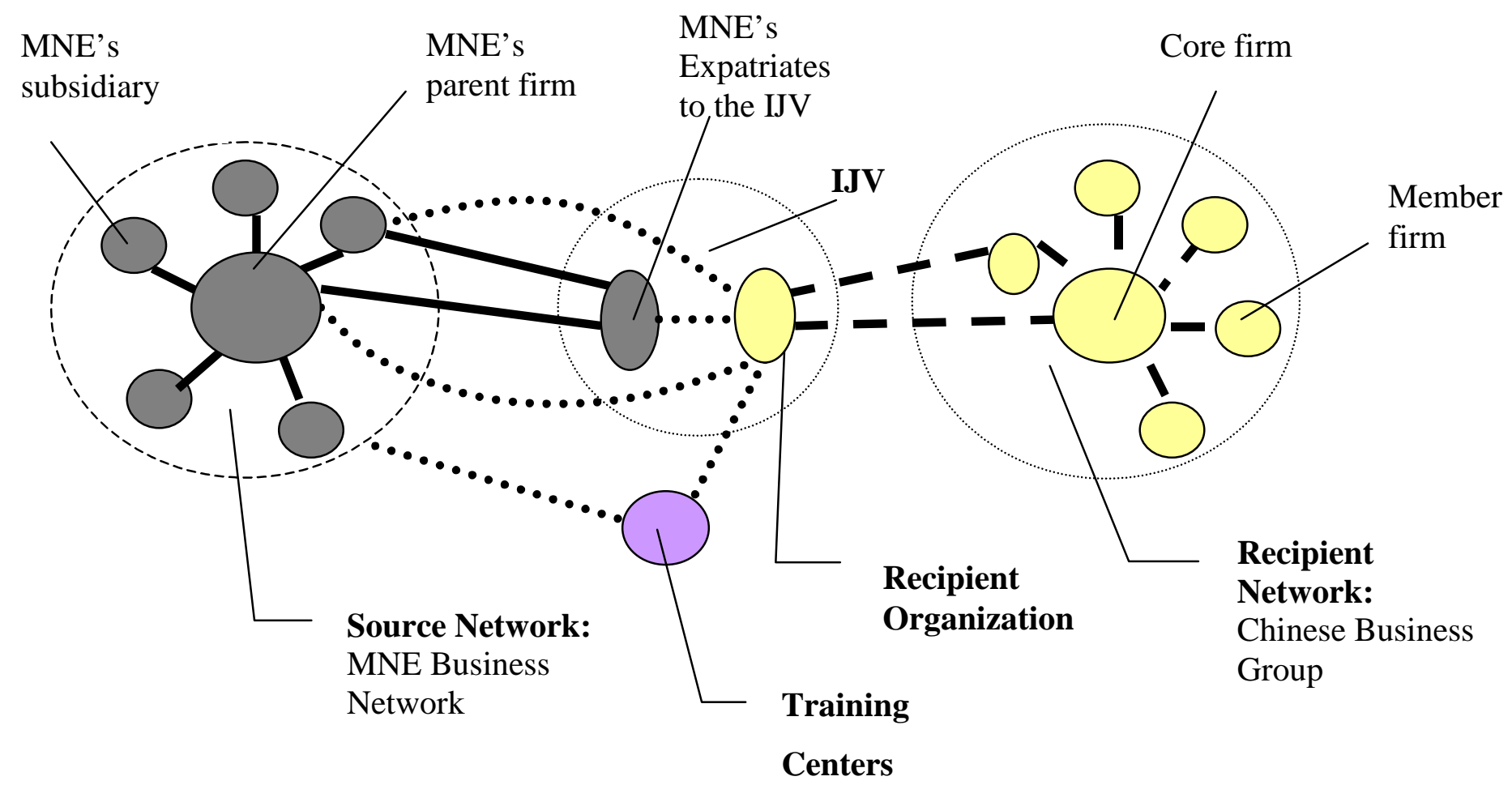

•...... Ties of Bridge Network

- Ties of Recipient Network

Ties of Source Network 


\section{Figure 2. The effect of a recipient network's stock of previous R\&D experience on the effectiveness of R\&D transfer in the IJV 『}

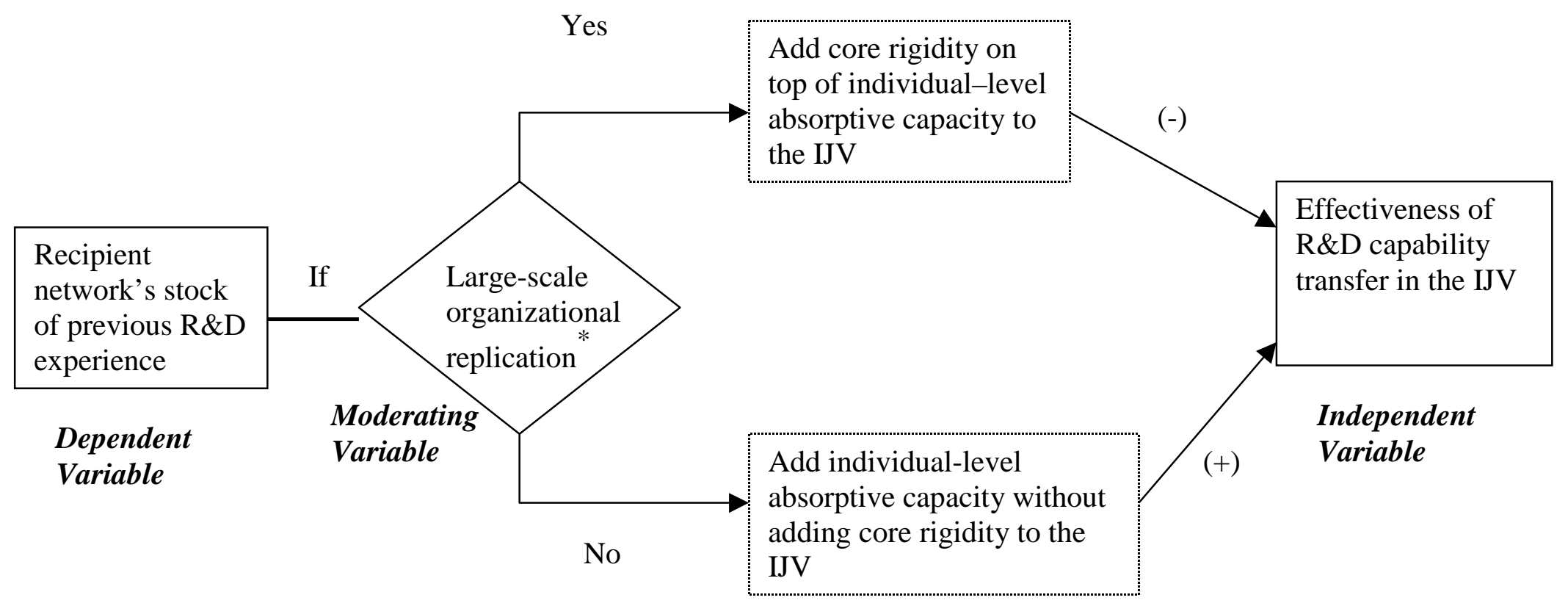

* This moderating variable defines the mechanism of R\&D personnel transfer from the recipient network to the recipient organization. Large-scale organization replication means that a large portion of R\&D personnel get transferred to the IJV from the recipient network's R\&D units without significant reorganization. In other words, the obsolete R\&D routines of a recipient network get transferred intact. 
Figure 3. Factors affect effectiveness of transfer of $R \& D$ capabilities

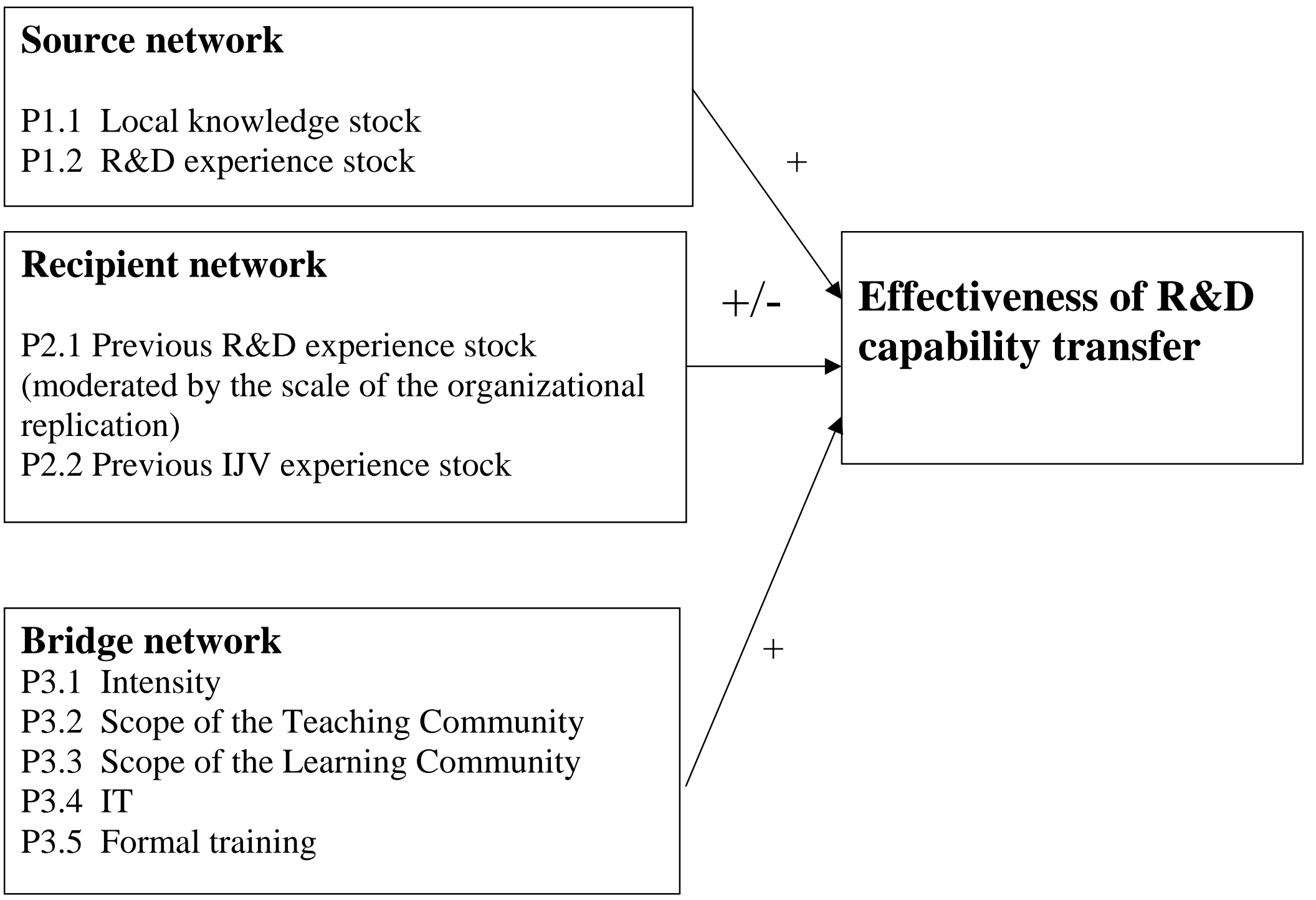




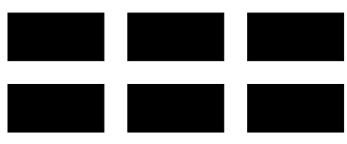

THE WILLIAM DAVIDSON INSTITUTE

AT THE UNIVERSITY OF MICHIGAN BUSINESSSCHOOL

\section{DAVIDSON INSTITUTE WORKING PAPER SERIES - Most Recent Papers}

The entire Working Paper Series is available at: www.wdi.bus.umich.edu

CURRENT AS OF $2 / 21 / 01$

\begin{tabular}{|c|c|c|}
\hline Publication & Authors & Date \\
\hline $\begin{array}{l}\text { No. } 362 \text { A Network Perspective on Inter-Organizational Transfer of } \\
\text { R\&D Capabilities: A Study of International Joint Ventures in Chinese } \\
\text { Automobile Industry }\end{array}$ & $\begin{array}{l}\text { Zheng Zhao, Jaideep Anand and } \\
\text { Will Mitchell }\end{array}$ & Feb. 2001 \\
\hline $\begin{array}{l}\text { No. } 361 \text { Network Restructuring and Firm Creation in East-Central } \\
\text { Europe: A Public-Private Venture }\end{array}$ & Gerald A. McDermott & Dec. 2000 \\
\hline $\begin{array}{l}\text { No. } 360 \text { Responses of Private and Public Schools to Voucher Funding: } \\
\text { The Czech and Hungarian Experience }\end{array}$ & $\begin{array}{l}\text { Randall K. Filer and Daniel } \\
\text { Münich }\end{array}$ & Oct. 2000 \\
\hline $\begin{array}{l}\text { No. } 359 \text { Labor Market Uncertainty and Private Sector Labor Supply in } \\
\text { Russia }\end{array}$ & Steven Stillman & Sept. 2000 \\
\hline $\begin{array}{l}\text { No. } 358 \text { Russian Roulette-Expenditure Inequality and Instability in } \\
\text { Russia, 1994-1998 }\end{array}$ & Branko Jovanovic & Sept. 2000 \\
\hline No. 357 Dealing with the Bad Loans of the Chinese Banks & John P. Bonin and Yiping Huang & Jan. 2001 \\
\hline No. 356 Retail Banking in Hungary: A Foreign Affair? & John P. Bonin and István Ábel & Dec. 2000 \\
\hline $\begin{array}{l}\text { No. } 355 \text { Optimal Speed of Transition: Micro Evidence from the Czech } \\
\text { Republic }\end{array}$ & $\begin{array}{l}\text { Stepan Jurajda and Katherine } \\
\text { Terrell }\end{array}$ & Dec. 2000 \\
\hline No. 354 Political Instability and Growth in Dictatorships & $\begin{array}{l}\text { Jody Overland, Kenneth L. } \\
\text { Simons and Michael Spagat }\end{array}$ & Nov. 2000 \\
\hline No. 353 Disintegration and Trade & Jarko Fidrmuc and Jan Fidrmuc & Nov. 2000 \\
\hline $\begin{array}{l}\text { No. } 352 \text { Social Capital and Entrepreneurial Performance in Russia: A } \\
\text { Panel Study }\end{array}$ & Bat Batjargal & Dec. 2000 \\
\hline $\begin{array}{l}\text { No. } 351 \text { Entrepreneurial Versatility, Resources and Firm Performance in } \\
\text { Russia: A Panel Study }\end{array}$ & Bat Batjargal & Dec. 2000 \\
\hline $\begin{array}{l}\text { No. } 350 \text { The Dynamics of Entrepreneurial Networks in a Transitional } \\
\text { Economy: The Case of Russia }\end{array}$ & Bat Batjargal & Dec. 2000 \\
\hline $\begin{array}{l}\text { No. } 349 \text { R\&D and Technology Spillovers via FDI: Innovation and } \\
\text { Absorptive Capacity }\end{array}$ & Yuko Kinoshita & Nov. 2000 \\
\hline $\begin{array}{l}\text { No. } 348 \text { Microeconomic aspects of Economic Growth in Eastern } \\
\text { Europe and the Former Soviet Union, 1950-2000 }\end{array}$ & Sergei Guriev and Barry W. Ickes & Nov. 2000 \\
\hline $\begin{array}{l}\text { No. } 347 \text { Effective versus Statutory Taxation: Measuring Effective Tax } \\
\text { Administration in Transition Economies }\end{array}$ & $\begin{array}{l}\text { Mark E. Schaffer and Gerard } \\
\text { Turley }\end{array}$ & Nov. 2000 \\
\hline $\begin{array}{l}\text { No. } 346 \text { Objectives and Constraints of Entrepreneurs: Evidence from } \\
\text { Small and Medium Size Enterprises in Russia and Bulgaria }\end{array}$ & $\begin{array}{l}\text { Francesca Pissarides, Miroslav } \\
\text { Singer and Jan Svejnar }\end{array}$ & Oct. 2000 \\
\hline No. 345 Corruption and Anticorruption in the Czech Republic & $\begin{array}{l}\text { Lubomír Lízal and Evžen } \\
\text { Kočenda }\end{array}$ & Oct. 2000 \\
\hline No. 344 The Effects of Direct Foreign Investment on Domestic Firms & Jozef Konings & Oct. 2000 \\
\hline No. 343 On the Identification of Relative Wage Rigidity Dynamics & Patrick A. Puhani & Oct. 2000 \\
\hline $\begin{array}{l}\text { No. } 342 \text { The Determinants of Foreign Direct Investment in Transition } \\
\text { Economies }\end{array}$ & Alan A. Bevan and Saul Estrin & Oct. 2000 \\
\hline No. 341 The Global Spread of Stock Exchanges, 1980-1998 & Klaus Weber and Gerald F. Davis & Nov. 2000 \\
\hline $\begin{array}{l}\text { No. } 340 \text { The Costs and Benefits of Euro-isation in Central-Eastern } \\
\text { Europe Before or Instead of EMU Membership }\end{array}$ & D. Mario Nuti & Oct. 2000 \\
\hline No. 339 Debt Overhang and Barter in Russia & $\begin{array}{l}\text { Sergei Guriev, Igor Makarov and } \\
\text { Mathilde Maurel }\end{array}$ & Sept. 2000 \\
\hline
\end{tabular}




\begin{tabular}{|c|c|c|}
\hline $\begin{array}{l}\text { No. } 338 \text { Firm Performance and the Political Economy of Corporate } \\
\text { Governance: Survey Evidence for Bulgaria, Hungary, Slovakia and } \\
\text { Slovenia }\end{array}$ & $\begin{array}{l}\text { Patrick Paul Walsh and Ciara } \\
\text { Whela }\end{array}$ & July 2000 \\
\hline No. 337 Investment and Instability & $\begin{array}{l}\text { Nauro F. Campos and Jeffrey B. } \\
\text { Nugent }\end{array}$ & May 2000 \\
\hline $\begin{array}{l}\text { No. } 336 \text { The Evolution of the Insurance Sector in Central and } \\
\text { Eastern Europe and the former Soviet Union }\end{array}$ & Robert B.K. Pye & Aug. 2000 \\
\hline $\begin{array}{l}\text { No. } 335 \text { Institutional Technology and the Chains of Trust: Capital } \\
\text { Markets and Privatization in Russia and the Czech Republic }\end{array}$ & Bruce Kogut and Andrew Spicer & Aug. 2000 \\
\hline No. 334 The Evolution of Market Integration in Russia & $\begin{array}{l}\text { Daniel Berkowitz and David N. } \\
\text { DeJong }\end{array}$ & Aug. 2000 \\
\hline No. 333 Efficiency and Market Share in Hungarian Corporate Sector & László Halpern and Gábor Körösi & July 2000 \\
\hline No. 332 Search-Money-and-Barter Models of Financial Stabilization & $\begin{array}{l}\text { S.I. Boyarchenko and S.Z. } \\
\text { Levendorskii }\end{array}$ & July 2000 \\
\hline $\begin{array}{l}\text { No. } 331 \text { Worker Training in a Restructuring Economy: Evidence from } \\
\text { the Russian Transition }\end{array}$ & $\begin{array}{l}\text { Mark C. Berger, John S. Earle } \\
\text { and Klara Z. Sabirianova }\end{array}$ & Aug. 2000 \\
\hline $\begin{array}{l}\text { No. } 330 \text { Economic Development in Palanpur 1957-1993: A Sort of } \\
\text { Growth }\end{array}$ & Peter Lanjouw & Aug. 2000 \\
\hline $\begin{array}{l}\text { No. } 329 \text { Trust, Organizational Controls, Knowledge Acquisition from } \\
\text { the Foreign Parents, and Performance in Vietnamese International Joint } \\
\text { Ventures }\end{array}$ & $\begin{array}{l}\text { Marjorie A. Lyles, Le Dang } \\
\text { Doanh, and Jeffrey Q. Barden }\end{array}$ & June 2000 \\
\hline $\begin{array}{l}\text { No. } 328 \text { Comparative Advertising in the Global Marketplace: The } \\
\text { Effects of Cultural Orientation on Communication }\end{array}$ & $\begin{array}{l}\text { Zeynep Gürhan-Canli and } \\
\text { Durairaj Maheswaran }\end{array}$ & Aug. 2000 \\
\hline No. 327 Post Privatization Enterprise Restructuring & Morris Bornstein & July 2000 \\
\hline No. 326 Who is Afraid of Political Instability? & $\begin{array}{l}\text { Nauro F. Campos and Jeffrey B. } \\
\text { Nugent }\end{array}$ & July 2000 \\
\hline No. 325 Business Groups, the Financial Market and Modernization & Raja Kali & June 2000 \\
\hline $\begin{array}{l}\text { No. } 324 \text { Restructuring with What Success? A Case Study of Russian } \\
\text { Firms }\end{array}$ & Susan Linz & July 2000 \\
\hline $\begin{array}{l}\text { No. } 323 \text { Priorities and Sequencing in Privatization: Theory and } \\
\text { Evidence from the Czech Republic }\end{array}$ & $\begin{array}{l}\text { Nandini Gupta, John C. Ham and } \\
\text { Jan Svejnar }\end{array}$ & May 2000 \\
\hline $\begin{array}{l}\text { No. } 322 \text { Liquidity, Volatility, and Equity Trading Costs Across } \\
\text { Countries and Over Time }\end{array}$ & $\begin{array}{l}\text { Ian Domowitz, Jack Glen and } \\
\text { Ananth Madhavan }\end{array}$ & Mar. 2000 \\
\hline $\begin{array}{l}\text { No. } 321 \text { Equilibrium Wage Arrears: A Theoretical and Empirical } \\
\text { Analysis of Institutional Lock-In }\end{array}$ & $\begin{array}{l}\text { John S. Earle and Klara Z. } \\
\text { Sabirianova }\end{array}$ & Oct. 2000 \\
\hline No. 320 Rethinking Marketing Programs for Emerging Markets & $\begin{array}{l}\text { Niraj Dawar and Amitava } \\
\text { Chattopadhyay }\end{array}$ & June 2000 \\
\hline $\begin{array}{l}\text { No. } 319 \text { Public Finance and Low Equilibria in Transition Economies: } \\
\text { the Role of Institutions }\end{array}$ & $\begin{array}{l}\text { Daniel Daianu and Radu } \\
\text { Vranceanu }\end{array}$ & June 2000 \\
\hline $\begin{array}{l}\text { No. } 318 \text { Some Econometric Evidence on the Effectiveness of Active } \\
\text { Labour Market Programmes in East Germany }\end{array}$ & $\begin{array}{l}\text { Martin Eichler and Michael } \\
\text { Lechner }\end{array}$ & June 2000 \\
\hline No. 317 A Model of Russia’s "Virtual Economy" & R.E Ericson and B.W Ickes & May 2000 \\
\hline $\begin{array}{l}\text { No. } 316 \text { Financial Institutions, Financial Contagion, and Financial } \\
\text { Crises }\end{array}$ & $\begin{array}{l}\text { Haizhou Huang and Chenggang } \\
\mathrm{Xu}\end{array}$ & Mar. 2000 \\
\hline $\begin{array}{l}\text { No. } 315 \text { Privatization versus Regulation in Developing Economies: The } \\
\text { Case of West African Banks }\end{array}$ & $\begin{array}{l}\text { Jean Paul Azam, Bruno Biais, and } \\
\text { Magueye Dia }\end{array}$ & Feb. 2000 \\
\hline $\begin{array}{l}\text { No. } 314 \text { Is Life More Risky in the Open? Household Risk-Coping and } \\
\text { the Opening of China's Labor Markets }\end{array}$ & John Giles & Apr. 2000 \\
\hline $\begin{array}{l}\text { No. } 313 \text { Networks, Migration and Investment: Insiders and Outsiders in } \\
\text { Tirupur's Production Cluster }\end{array}$ & $\begin{array}{l}\text { Abhijit Banerjee and Kaivan } \\
\text { Munshi }\end{array}$ & Mar. 2000 \\
\hline $\begin{array}{l}\text { No. } 312 \text { Computational Analysis of the Impact on India of the Uruguay } \\
\text { Round and the Forthcoming WTO Trade Negotiations }\end{array}$ & $\begin{array}{l}\text { Rajesh Chadha, Drusilla K. } \\
\text { Brown, Alan V. Deardorff and } \\
\text { Robert M. Stern }\end{array}$ & Mar. 2000 \\
\hline No. 311 Subsidized Jobs for Unemployed Workers in Slovakia & Jan. C. van Ours & May 2000 \\
\hline No. 310 Determinants of Managerial Pay in the Czech Republic & $\begin{array}{l}\text { Tor Eriksson, Jaromir Gottvald } \\
\text { and Pavel Mrazek }\end{array}$ & May 2000 \\
\hline
\end{tabular}




\begin{tabular}{|c|c|c|}
\hline $\begin{array}{l}\text { No. } 309 \text { The Great Human Capital Reallocation: An Empirical Analysis } \\
\text { of Occupational Mobility in Transitional Russia }\end{array}$ & Klara Z. Sabirianova & Oct. 2000 \\
\hline No. 308 Economic Development, Legality, and the Transplant Effect & $\begin{array}{l}\text { Daniel Berkowitz, Katharina } \\
\text { Pistor, and Jean-Francois Richard }\end{array}$ & Feb. 2000 \\
\hline $\begin{array}{l}\text { No. } 307 \text { Community Participation, Teacher Effort, and Educational } \\
\text { Outcome: The Case of El Salvador's EDUCO Program }\end{array}$ & Yasuyuki Sawada & Nov. 1999 \\
\hline No. 306 Gender Wage Gap and Segregation in Late Transition & Stepan Jurajda & May 2000 \\
\hline $\begin{array}{l}\text { No. } 305 \text { The Gender Pay Gap in the Transition from Communism: } \\
\text { Some Empirical Evidence }\end{array}$ & Andrew Newell and Barry Reilly & May 2000 \\
\hline No. 304 Post-Unification Wage Growth in East Germany & Jennifer Hunt & Nov. 1998 \\
\hline $\begin{array}{l}\text { No. } 303 \text { How Does Privatization Affect Workers? The Case of the } \\
\text { Russian Mass Privatization Program }\end{array}$ & Elizabeth Brainerd & May 2000 \\
\hline $\begin{array}{l}\text { No. } 302 \text { Liability for Past Environmental Contamination and } \\
\text { Privatization }\end{array}$ & Dietrich Earnhart & Mar. 2000 \\
\hline No. 301 Varieties, Jobs and EU Enlargement & $\begin{array}{l}\text { Tito Boeri and Joaquim Oliveira } \\
\text { Martins }\end{array}$ & May 2000 \\
\hline No. 300 Employer Size Effects in Russia & Todd Idson & Apr. 2000 \\
\hline $\begin{array}{l}\text { No. } 299 \text { Information Complements, Substitutes, and Strategic Product } \\
\text { Design }\end{array}$ & $\begin{array}{l}\text { Geoffrey G. Parker and Marshall } \\
\text { W. Van Alstyne }\end{array}$ & Mar. 2000 \\
\hline $\begin{array}{l}\text { No. } 298 \text { Markets, Human Capital, and Inequality: Evidence from Rural } \\
\text { China }\end{array}$ & $\begin{array}{l}\text { Dwayne Benjamin, Loren Brandt, } \\
\text { Paul Glewwe, and Li Guo }\end{array}$ & May 2000 \\
\hline No. 297 Corporate Governance in the Asian Financial Crisis & $\begin{array}{l}\text { Simon Johnson, Peter Boone, } \\
\text { Alasdair Breach, and Eric } \\
\text { Friedman }\end{array}$ & Nov. 1999 \\
\hline No. 296 Competition and Firm Performance: Lessons from Russia & J. David Brown and John S. Earle & Mar. 2000 \\
\hline No. 295 Wage Determination in Russia: An Econometric Investigation & $\begin{array}{l}\text { Peter J. Luke and Mark E. } \\
\text { Schaffer }\end{array}$ & Mar. 2000 \\
\hline $\begin{array}{l}\text { No. 294: Can Banks Promote Enterprise Restructuring?: Evidence From } \\
\text { a Polish Bank's Experience }\end{array}$ & John P. Bonin and Bozena Leven & Mar. 2000 \\
\hline No. 293: Why do Governments Sell Privatised Companies Abroad? & $\begin{array}{l}\text { Bernardo Bortolotti, Marcella } \\
\text { Fantini and Carlo Scarpa }\end{array}$ & Mar. 2000 \\
\hline $\begin{array}{l}\text { No. 292: Going Public in Poland: Case-by-Case Privatizations, Mass } \\
\text { Privatization and Private Sector Initial Public Offerings }\end{array}$ & Wolfgang Aussenegg & Dec. 1999 \\
\hline $\begin{array}{l}\text { No. 291: Institutional Technology and the Chains of Trust: Capital } \\
\text { Markets and Privatization in Russia and the Czech Republic }\end{array}$ & Bruce Kogut and Andrew Spicer & Mar. 1999 \\
\hline No. 290: Banking Crises and Bank Rescues: The Effect of Reputation & Jenny Corbett and Janet Mitchell & Jan. 2000 \\
\hline $\begin{array}{l}\text { No. 289: Do Active Labor Market Policies Help Unemployed Workers } \\
\text { to Find and Keep Regular Jobs? }\end{array}$ & Jan C. van Ours & Feb. 2000 \\
\hline No. 288: Consumption Patterns of the New Elite in Zimbabwe & Russell Belk & Feb. 2000 \\
\hline $\begin{array}{l}\text { No. 287: Barter in Transition Economies: Competing Explanations } \\
\text { Confront Ukranian Data }\end{array}$ & $\begin{array}{l}\text { Dalia Marin, Daniel Kaufmann } \\
\text { and Bogdan Gorochowskij }\end{array}$ & Jan. 2000 \\
\hline $\begin{array}{l}\text { No. 286: The Quest for Pension Reform: Poland's Security through } \\
\text { Diversity }\end{array}$ & $\begin{array}{l}\text { Marek Góra and Michael } \\
\text { Rutkowski }\end{array}$ & Jan. 2000 \\
\hline No. 285: Disorganization and Financial Collapse & $\begin{array}{l}\text { Dalia Marin and Monika } \\
\text { Schnitzer }\end{array}$ & Oct. 1999 \\
\hline No. 284: Coordinating Changes in M-form and U-form Organizations & $\begin{array}{l}\text { Yingyi Qian, Gérard Roland and } \\
\text { Chenggang Xu }\end{array}$ & May 1999 \\
\hline $\begin{array}{l}\text { No. 283: Why Russian Workers Do Not Move: Attachment of Workers } \\
\text { Through In-Kind Payments }\end{array}$ & Guido Friebel and Sergei Guriev & Oct. 1999 \\
\hline No. 282: Lessons From Fiascos in Russian Corporate Governance & $\begin{array}{l}\text { Merritt B. Fox and Michael A. } \\
\text { Heller }\end{array}$ & Oct. 1999 \\
\hline $\begin{array}{l}\text { No. 281: Income Distribution and Price Controls: Targeting a Social } \\
\text { Safety Net During Economic Transition }\end{array}$ & $\begin{array}{l}\text { Michael Alexeev and James } \\
\text { Leitzel }\end{array}$ & Mar. 1999 \\
\hline $\begin{array}{l}\text { No. 280: Starting Positions, Reform Speed, and Economic Outcomes in } \\
\text { Transitioning Economies }\end{array}$ & William Hallagan and Zhang Jun & Jan. 2000 \\
\hline
\end{tabular}




\begin{tabular}{|c|c|c|}
\hline No. 279 : The Value of Prominent Directors & $\begin{array}{l}\text { Yoshiro Miwa \& J. Mark } \\
\text { Ramseyer }\end{array}$ & Oct. 1999 \\
\hline No. 278: The System Paradigm & János Kornai & Apr. 1998 \\
\hline $\begin{array}{l}\text { No. 277: The Developmental Consequences of Foreign Direct } \\
\text { Investment in the Transition from Socialism to Capitalism: The } \\
\text { Performance of Foreign Owned Firms in Hungary }\end{array}$ & Lawrence Peter King & Sept. 1999 \\
\hline $\begin{array}{l}\text { No. 276: Stability and Disorder: An Evolutionary Analysis of Russia's } \\
\text { Virtual Economy }\end{array}$ & $\begin{array}{l}\text { Clifford Gaddy and Barry W. } \\
\text { Ickes }\end{array}$ & Nov. 1999 \\
\hline $\begin{array}{l}\text { No. 275: Limiting Government Predation Through Anonymous } \\
\text { Banking: A Theory with Evidence from China. }\end{array}$ & $\begin{array}{l}\text { Chong-En Bai, David D. Li, } \\
\text { Yingyi Qian and Yijiang Wang }\end{array}$ & July 1999 \\
\hline No. 274: Transition with Labour Supply & Tito Boeri & Dec. 1999 \\
\hline $\begin{array}{l}\text { No. 273: Sectoral Restructuring and Labor Mobility: A Comparative } \\
\text { Look at the Czech Republic }\end{array}$ & Vit Sorm and Katherine Terrell & Nov. 1999 \\
\hline $\begin{array}{l}\text { No. 272: Published in: Journal of Comparative Economics "Returns to } \\
\text { Human Capital Under the Communist Wage Grid and During the } \\
\text { Transition to a Market Economy" Vol. 27, pp. 33-60 1999. }\end{array}$ & $\begin{array}{l}\text { Daniel Munich, Jan Svejnar and } \\
\text { Katherine Terrell }\end{array}$ & Oct. 1999 \\
\hline $\begin{array}{l}\text { No. 271: Barter in Russia: Liquidity Shortage Versus Lack of } \\
\text { Restructuring }\end{array}$ & $\begin{array}{l}\text { Sophie Brana and Mathilde } \\
\text { Maurel }\end{array}$ & June 1999 \\
\hline $\begin{array}{l}\text { No. 270: Tests for Efficient Financial Intermediation with Application to } \\
\text { China }\end{array}$ & Albert Park and Kaja Sehrt & Mar. 1999 \\
\hline $\begin{array}{l}\text { No. 269a: Russian Privatization and Corporate Governance: What Went } \\
\text { Wrong? }\end{array}$ & $\begin{array}{l}\text { Bernard Black, Reinier Kraakman } \\
\text { and Anna Tarassova }\end{array}$ & May 2000 \\
\hline $\begin{array}{l}\text { No. 269: Russian Privatization and Corporate Governance: What Went } \\
\text { Wrong? }\end{array}$ & $\begin{array}{l}\text { Bernard Black, Reinier Kraakman } \\
\text { and Anna Tarassova }\end{array}$ & Sept. 1999 \\
\hline No. 268: Are Russians Really Ready for Capitalism? & Susan Linz & Sept. 1999 \\
\hline No. 267: Do Stock Markets Promote Economic Growth? & $\begin{array}{l}\text { Randall K. Filer, Jan Hanousek } \\
\text { and Nauro Campos }\end{array}$ & Sept. 1999 \\
\hline $\begin{array}{l}\text { No. 266: Objectivity, Proximity and Adaptability in Corporate } \\
\text { Governance }\end{array}$ & $\begin{array}{l}\text { Arnoud W.A Boot and Jonathan } \\
\text { R. Macey }\end{array}$ & Sept. 1999 \\
\hline $\begin{array}{l}\text { No. 265: When the Future is not What it Used to Be: Lessons from the } \\
\text { Western European Experience to Forecasting Education and Training in } \\
\text { Transitional Economies }\end{array}$ & $\begin{array}{l}\text { Nauro F. Campos, Gerard } \\
\text { Hughes, Stepan Jurajda, and } \\
\text { Daniel Munich }\end{array}$ & Sept. 1999 \\
\hline $\begin{array}{l}\text { No. 264: The Institutional Foundation of Foreign-Invested Enterprises } \\
\text { (FIEs) in China }\end{array}$ & Yasheng Huang & Sept. 1999 \\
\hline $\begin{array}{l}\text { No. 263: The Changing Corporate Governance Paradigm: Implications } \\
\text { for Transition and Developing Countries }\end{array}$ & $\begin{array}{l}\text { Erik Berglof and Ernst-Ludwig } \\
\text { von Thadden }\end{array}$ & June 1999 \\
\hline No. 262: Law Enforcement and Transition & $\begin{array}{l}\text { Gerard Roland and Thierry } \\
\text { Verdier }\end{array}$ & May 1999 \\
\hline $\begin{array}{l}\text { No. 261: Soft Budget Constraints, Pecuniary Externality, and the Dual } \\
\text { Track System }\end{array}$ & Jiahua Che & June 2000 \\
\hline $\begin{array}{l}\text { No. 260: Missing Market in Labor Quality: The Role of Quality Markets } \\
\text { in Transition }\end{array}$ & Gary H. Jefferson & July 1999 \\
\hline $\begin{array}{l}\text { No. 259: Do Corporate Global Environmental Standards in Emerging } \\
\text { Markets Create or Destroy Market Value }\end{array}$ & $\begin{array}{l}\text { Glen Dowell, Stuart Hart and } \\
\text { Bernard Yeung }\end{array}$ & June 1999 \\
\hline No. 258: Public Training and Outflows from Unemployment & Patrick A. Puhani & June 1999 \\
\hline $\begin{array}{l}\text { No. 257: Ownership Versus Environment: Why are Public Sector Firms } \\
\text { Inefficient? }\end{array}$ & $\begin{array}{l}\text { Ann P. Bartel and Ann E. } \\
\text { Harrison }\end{array}$ & June 1999 \\
\hline $\begin{array}{l}\text { No. 256: Taxation and Evasion in the Presence of Exortion by } \\
\text { Organized Crime }\end{array}$ & $\begin{array}{l}\text { Michael Alexeev, Eckhard Janeba } \\
\text { and Stefan Osborne }\end{array}$ & Nov. 1999 \\
\hline No. 255: Revisiting Hungary’s Bankruptcy Episode & $\begin{array}{l}\text { John P. Bonin and Mark E. } \\
\text { Schaffer }\end{array}$ & Sept. 1999 \\
\hline No. 254: FDI in Emerging Markets: A Home-Country View & Marina v.N Whitman & June 1999 \\
\hline $\begin{array}{l}\text { No. 253: The Asian Financial Crisis: What Happened, and What is to be } \\
\text { Done }\end{array}$ & $\begin{array}{l}\text { Jeffrey D. Sachs and Wing Thye } \\
\text { Woo }\end{array}$ & Jan. 1999 \\
\hline No. 252: Organizational Law as Asset Partitioning & $\begin{array}{l}\text { Henry Hansmann and Reinier } \\
\text { Kraakman }\end{array}$ & Sept. 1999 \\
\hline
\end{tabular}

